Review

\title{
Therapeutic Status and Available Strategies in Pancreatic Ductal Adenocarcinoma
}

\author{
Gitika Thakur ${ }^{1}{ }^{\oplus}$, Raj Kumar $^{2}{ }^{\mathbb{D}}$, Saet-Byul Kim ${ }^{1}$, Sang-Yeob Lee ${ }^{1}$, Sung-Lim Lee ${ }^{1}$ and Gyu-Jin Rho ${ }^{1, *}$ \\ 1 Department of Theriogenology and Biotechnology, College of Veterinary Medicine and Research Institute of \\ Life Science, Gyeongsang National University, Jinju 52828, Korea; gitika18oct@gnu.ac.kr (G.T.); \\ sbkim4@gnu.ac.kr (S.-B.K.); sylee2@gnu.ac.kr (S.-Y.L.); sllee@gnu.ac.kr (S.-L.L.) \\ 2 Department of Biotechnology and Bioinformatics, Jaypee University of Information Technology, \\ Waknaghat, Solan 173 234, Himachal Pradesh, India; raj.kumar@juit.ac.in \\ * Correspondence: jinrho@gnu.ac.kr
}

Citation: Thakur, G.; Kumar, R.; Kim, S.-B.; Lee, S.-Y.; Lee, S.-L.; Rho, G.-J. Therapeutic Status and Available Strategies in Pancreatic Ductal Adenocarcinoma. Biomedicines 2021, 9, 178. https://doi.org/10.3390/ biomedicines 9020178

Academic Editor: Rossano Lattanzio

Received: 29 December 2020

Accepted: 8 February 2021

Published: 11 February 2021

Publisher's Note: MDPI stays neutral with regard to jurisdictional claims in published maps and institutional affiliations.

Copyright: (c) 2021 by the authors. Licensee MDPI, Basel, Switzerland. This article is an open access article distributed under the terms and conditions of the Creative Commons Attribution (CC BY) license (https:// creativecommons.org/licenses/by/ $4.0 /)$.
Abstract: One of the most severe and devastating cancer is pancreatic cancer. Pancreatic ductal adenocarcinoma (PDAC) is one of the major pancreatic exocrine cancer with a poor prognosis and growing prevalence. It is the most deadly disease, with an overall five-year survival rate of $6 \%$ to $10 \%$. According to various reports, it has been demonstrated that pancreatic cancer stem cells (PCSCs) are the main factor responsible for the tumor development, proliferation, resistance to anti-cancer drugs, and recurrence of tumors after surgery. PCSCs have encouraged new therapeutic methods to be explored that can specifically target cancer cells. Furthermore, stem cells, especially mesenchymal stem cells (MSCs), are known as influential anti-cancer agents as they function through anti-inflammatory, paracrine, cytokines, and chemokine's action. The properties of MSCs, such as migration to the site of infection and host immune cell activation by its secretome, seem to control the microenvironment of the pancreatic tumor. MSCs secretome exhibits similar therapeutic advantages as a conventional cell-based therapy. Moreover, the potential for drug delivery could be enhanced by engineered MSCs to increase drug bioactivity and absorption at the tumor site. In this review, we have discussed available therapeutic strategies, treatment hurdles, and the role of different factors such as PCSCs, cysteine, GPCR, PKM2, signaling pathways, immunotherapy, and NK-based therapy in pancreatic cancer.

Keywords: pancreatic cancer; pancreatic ductal adenocarcinoma; stem cells; pancreatic cancer stem cells

\section{Introduction}

The pancreas is an organ located in the abdomen having both exocrine and endocrine functions. It plays an essential role in the digestion of food by releasing enzymes from its exocrine part, maintains blood glucose level by producing two major hormones: glucagon and insulin secreted from the endocrinal region of the pancreas. Normal healthy cells become cancerous when a series of changes take place in the DNA sequence, leads the cell to divide uncontrollably and migrate to adjacent cells. Cancer is the second leading cause of death worldwide and was accountable for an estimated 9.6 million deaths in 2018 (World Health Organization (WHO), 2018). It is the major public health issue and the main cause of death in Korea [1], second leading in the United States [2], and one of the leading causes of death in India [3]. One of the leading causes of cancer mortality and the most deadly malignant neoplasm is pancreatic cancer [4]. In 2012, around 338,000 individuals had pancreatic cancer worldwide, making it the eleventh most prevalent cancer. Around 458,918 new pancreatic cancer cases were identified worldwide in 2018, representing $2.5 \%$ of all cancers [5]. The American Cancer Society estimated about 57,600 new cases $(30,400$ male and 27,200 female) of pancreatic cancer and predicted that 47,050 patients (24,640 male and 22,410 female) will die of pancreatic cancer in 2020 [2]. In 2019, pancreatic 
cancer was the fourth leading cause of cancer deaths. It has been projected to become the second leading cause by 2030 [6,7].

Pancreatic cancer arises when cells in the pancreas start to divide uncontrollably and form a mass. There are different types of cancer cells based on their origin, for example, carcinoma (cancer of epithelial cells), sarcoma (cancer of mesenchymal cells in blood vessels, muscles, and other tissues), myeloma/leukemia/lymphoma (blood cell-related cancer), and adenocarcinoma (cancer of mucus-producing glandular cells). Two main subtypes of pancreatic cancer have been narrowly classified into exocrine and endocrine. Pancreatic ductal adenocarcinoma (PDAC) is an exocrine cell tumor mainly of the ductal cells, more common $(>85 \%)$ than endocrine cell tumors $(<5 \%)$ [8]. About $50 \%$ of PDACs are detected when the tumor is locally invasive or metastatic. PDAC has a 5 -year survival rate of $6 \%$ (ranges from 2\% to 10\%) [6,9]. Exocrine cancer is the most common form of pancreatic cancer, which comprises $95 \%$ of all pancreatic cancers $[10,11]$. Out of all exocrine cancers, the most common and aggressive form is ductal cancer, i.e., PDAC. It is one of the most malignant tumors, characterized by uncontrollable growth [9]. Approximately 85\% to $90 \%$ of pancreatic cancers are PDAC [11]. Recently, researchers have reviewed the current therapeutic options, dysregulated pathways, tumor microenvironment, and many other factors associated with PDAC [6,12]. Approximately $60 \%$ to $70 \%$ of cases emerge from the head of the pancreas, which comprises the bile duct; these cases are typically diagnosed earlier than body and tail tumors [13]. Tail and body tumors are linked with a poorer prognosis [14]. In patients with PDAC, the most common symptoms are abdominal pain, weight loss, and jaundice [15], whereas the new onset of type 2 diabetes is a less common symptom [16].

Additionally, studies have shown that PDAC and diabetes are co-related; at the time of cancer diagnosis, one- to two-thirds of patients with PDAC are diabetic [17]. The key concern is whether the growth of cancer is susceptible to diabetes or the consequence of the tumor is diabetes. The five leading behavioral and dietary risks, such as high body mass index, low consumption of fruit and vegetables, physical inactivity, alcohol, and tobacco, are responsible for about one-third of cancer deaths [4]. About 8\% of pancreatic cancers occur in families who carry mutations in tumor suppressor genes, including P16Ink4a/CDKN2A, BRCA2, MLH1, MSH2, STK1, or VHL [18]. In 95\% of PDAC cases, activating mutations in the KRAS oncogene are detected, but agents that can successfully target this high prevalence change in PDAC are not yet available. Available traditional strategies: surgery, radiation, and chemotherapy have been widely used, but no significant improvements have been shown. Overall survival remains poor for metastatic cancer, with less than $20 \%$ of patients surviving after the end of the first year [19]. For the better treatment of PDAC, alternative treatment approaches are desperately needed. Furthermore, stem cell therapy, which has shown therapeutic efficacy for solid tumors (breast, prostate, and lung carcinomas), can be one of the best options to treat PDAC [20]. This review will assist researchers to better understand the available treatment strategies, treatment hurdles, and the role of stem cells, mainly MSCs (Mesenchymal stem cells), in pancreatic cancer, especially in PDAC. Stem cells can be used for regenerative medicine, cancer stem-cell-targeted treatment, anticancer drug screening applications, and immunotherapy.

\section{Treatment Hurdles}

Treatment with cytotoxic agents: FOLFIRINOX (a mixture of Leucovorin and other chemotherapy medicines: Fluorouracil (5FU), Irinotecan and Oxaliplatin]) or Gemcitabine/ $\mathrm{Nab}$-paclitaxel is the current drug therapy for PDAC. In recent decades, these cytotoxic agents and other approved drugs (e.g., Erlotinib) used to treat PDAC have been shown to improve survival by a few months [21]. Furthermore, late diagnosis is responsible for a poor prognosis of PDAC. Due to the prevalence of metastatic spread and the local involvement of major blood vessels, over $80 \%$ of cases are not suitable for surgical resection of tumors [22]. In order to identify the specific characteristics of patients with less than 5 years of survival in the past 30 years, a Finnish study analyzed PDAC patient records. More than $50 \%$ of 
the cases with 5-year survival were incorrectly diagnosed with PDAC; even for those with the correct diagnosis, only one person with PDAC survived to 11 years [23]. Therefore, discovering new treatments for PDAC is a major unmet medical need.

\section{Stem Cells}

There are various stem cell therapies based on natural killer cells, activated $\mathrm{T}$ cells, and dendritic cells, which are extremely effective in treating cancer. Stem cells can be isolated from the embryonic (Embryonic stem cells: ESCs) and adult (Mesenchymal stem cells: MSCs) tissues, but their properties are different. Stem cells are known as influential anti-cancer agents as they function through anti-inflammatory, paracrine, cytokines, and chemokine's action and are proficient in regulating the tumor microenvironment. Stem cells have shown tremendous promise as therapeutic options for the next generation. In 2019, Chopra et al. reviewed the stem cell-based clinical trials, where different types of stem cells are used for the treatment of various cancers [24]. Around 544 clinical trials are currently enlisting patients (above 500 for hematopoietic stem cells and 12 for MSCs) for stem cell therapy to cure various cancers. Outcome measures, improved overall survival period, the accomplishment of complete or partial cancer-free status, and minimized serious negative effects have been evaluated in these studies. Until now, few studies have been performed on pancreatic cancer (particularly for PDAC) based on stem cell therapy. Merely four experiments using hematopoietic stem cells have been registered on clinicaltrials.gov, while none were registered with MSCs [24]. MSCs have unique immunomodulatory, inflammatory properties, homing capacity, and migration capability; consequently, they can migrate to the site of infection or inflammation $[25,26]$. Immunomodulatory factors, iNOS, IDO, TGF- $\beta$, LIF, PGE-2, and many others are secreted by MSCs to inhibit T cell proliferation $[27,28]$. Such factors can modulate the microenvironment of the tumor cells (Figure 1). In 2009, Cousin et al. investigated the capability of human adipose derived MSCs to cure PDAC in mice models and a cell line. They suggested that MSCs induce cell cycle inhibition at the G1 stage and downregulation of cyclin D1 and CDK4 that lead to cell death [29]. Furthermore, umbilical cord MSCs ability to reduce murine pancreatic cancer cell growth was tested using a mouse peritoneal model, which consequently caused a proliferation decline and caused cell death [30]. Another study has targeted PDAC using oral MSCs [31]. The above discussed studies suggested MSCs as a promising therapy for targeting PDAC and other pancreatic cancer. A generally activated pathway believed to be involved in PDAC pathogenesis is the WNT signaling pathway. The WNT pathway has been controlled by MSCs through the upregulation of dickkop-related protein 1 expression that further disturbs the cell cycle in tumors [32]. In prostate and colon tumor cells, MSCs have also been shown to promote fibroblast cell proliferation and angiogenesis. Therefore, when interacting with tumor cells, MSCs tend to act as a double edge sword [33].

\subsection{Cancer Stem Cells}

Cancer stem cells (CSCs) are mainly responsible for metastasis, recurrence of tumors, and resistance to anti-cancer drugs in pancreatic cancer, including PDAC [34]. The first existence of CSCs was reported in 1997 [35]. Proper understanding of pancreatic cancer stem cells (PCSCs) is a promising way to develop new opportunities for prevention and prognosis; PCSCs prompted new therapeutic methods to be explored that can specifically target cancer cells. CSCs are an unusual cancer cell population capable of self-renewal and division [36]. Cancer cells are found in a special niche comprised of a hypoxic/necrotic microenvironment comprising fibroblasts, perivascular cells, endothelial, and immune, along with extracellular matrix elements, growth factors, and cytokines (Figure 2). The plasticity of CSCs is another important factor that plays a major role in tumor progression and therapeutic resistance, as they have an increased ability to adapt to challenges or reprogram their metabolism and presented by drug therapy and the tumor microenvironment $[36,37]$. CSCs shift their microenvironment by attaining intermediate metabolic phenotypes and shifts their metabolism from oxidative phosphorylation to glycolysis. The main factors 
and signaling pathways which are necessary for self-renewal, resistance to available strategies, and epithelial to mesenchymal transition (EMT) consist of WNT/ $\beta$-catenin, Notch, and Sonic Hedgehog (SHH). PCSCs are highly resistant and can withstand traditional therapies that interfere with the complete eradication of cancerous cells [38]. Interestingly, PCSCs co-exist with other components of the tumor microenvironment, and to improve the understanding of PCSCs biology, it is essential to understand the correlation between these factors and PCSCs [34]. Chemo-resistance, together with metastatic potential, are the main clinical hallmarks of PCSCs. Metabolic inactivation and efflux of the drug from the cells as well as dysregulation/mutations in the drug targets, are responsible for the chemo-resistance of CSCs [38,39].

\subsection{Potential Approaches Targeting PCSCs}

Formulation of anti-cancer drugs to target associated proteins and pathways, thus improving chemotherapeutic efficacy [40]. Destruction of PCSCs should be able to avoid further tumor growth [41]. Prospective approaches are discussed below to target PCSCs. Anti-cancerous and non-cancer related drugs are listed in Table 1, whereas some drugs are used in combination (Table 2).

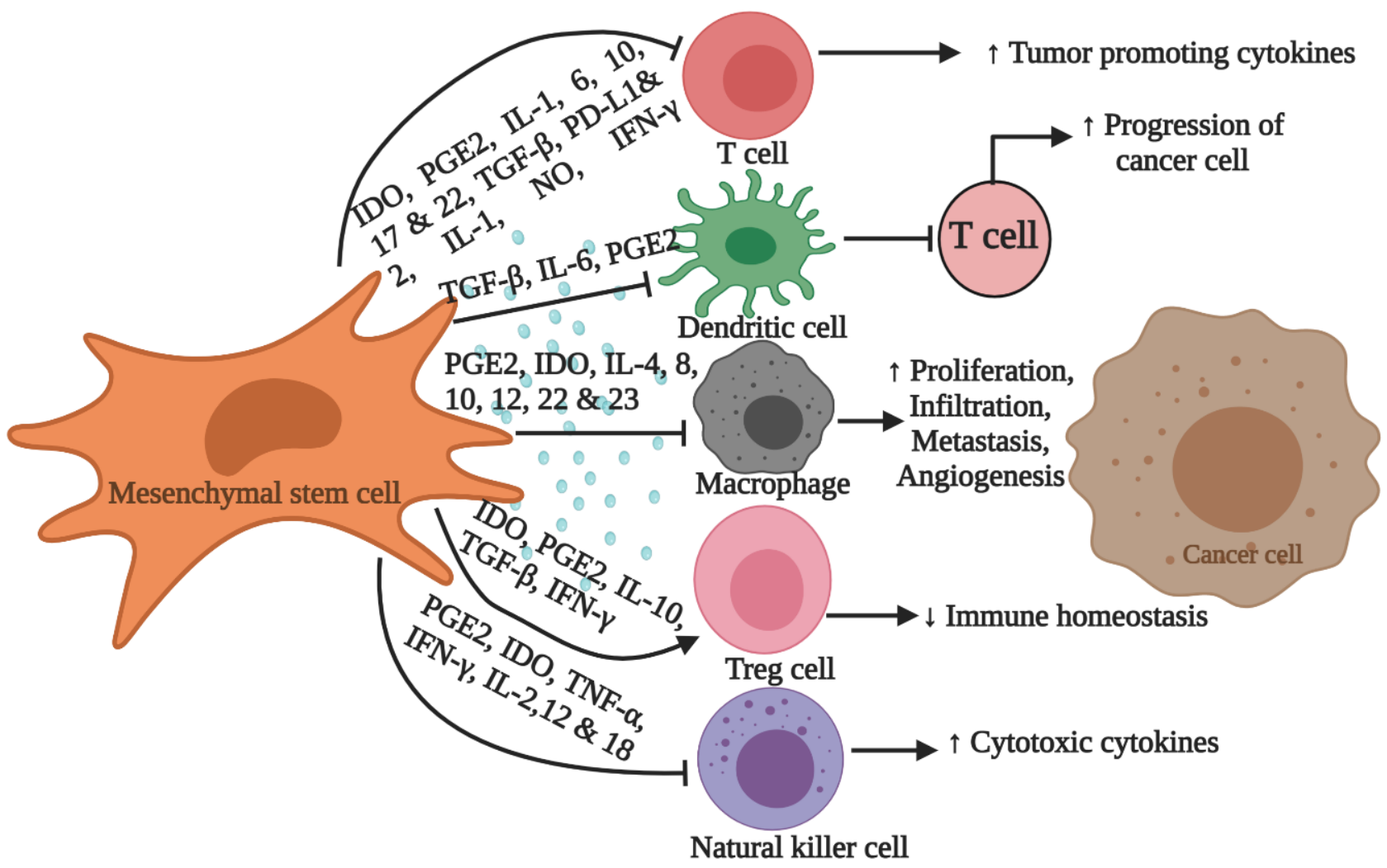

Figure 1. Immune cells in mesenchymal stem cells (MSCs) and cancer cell microenvironment. MSCs regulate the immune system by inducing Treg cells along with suppressing cytotoxic and helper T cells through TGF $\beta$, IL-10, PGE2, NO, and IDO. Cytokines secretions are also regulated by MSCs, by inhibiting macrophage and natural killer cells via PGE2 and IDO. In cancer cells, tumor growth and progression are increased through the inhibition of $\mathrm{T}$ cells by dendritic cells, and this action of dendritic cells is suppressed by immunomodulatory factors secreted by MSCs. IL: interleukin; TGF- $\beta$ : transforming growth factor beta; PGE2: prostaglandin E2; NO: nitric oxide; PD-L: programmed death-ligand; IDO: indoleamine 2,3-dioxygenase; Treg: T regulatory cell; $\rightarrow$ : activation; $\dashv$ : inhibition. Figure created with BioRender.com and modified from [24]. 


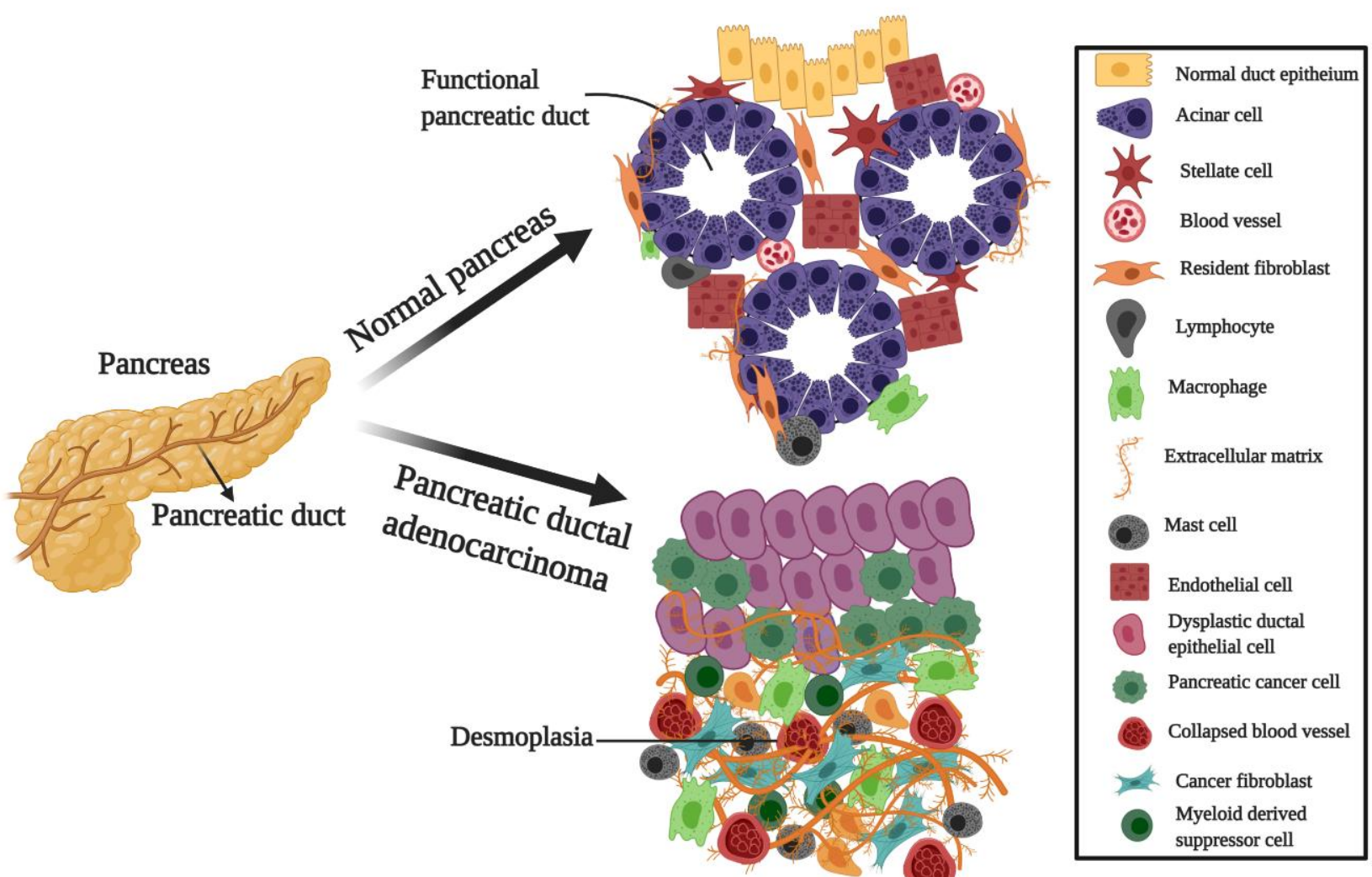

Figure 2. Pancreatic ductal adenocarcinoma microenvironment. Normal/healthy pancreas: pancreatic ducts and acinar cells are lined by epithelial cells in the healthy exocrine pancreas, the peri-acinar space is surrounded by resident fibroblasts and pancreatic stellate cells, and the extracellular matrix is mainly confined to interlobular septa and pancreatic ducts. Pancreatic ductal adenocarcinoma (PDAC) cells invade the basal membrane of dysplastic pancreatic ducts and infiltrate the healthy tissue. This infiltration is followed by a heavy desmoplasia in which pancreatic stellate cells are activated to tumor fibroblasts, and extracellular matrix components are synthesized in excess-figure created with BioRender.com and modified from [12]. 
Table 1. List of Food and Drug Administration (FDA) approved drugs and their potential effects on pancreatic cancer stem cells.

\begin{tabular}{|c|c|c|c|c|c|}
\hline Drug & Structure & Pathway in Volved & Mechanism of Action & Accession Number & References \\
\hline Salinomycin & & WNT/EMT & Inhibits the growth of CSCs & DB11544 & [42] \\
\hline Nigericin & & EMT & Inhibit the cell viability & DB14056 & {$[43]$} \\
\hline Azithromycin & & Mitochondria & $\begin{array}{l}\text { Inhibiting protein synthesis } \\
\text { and translation }\end{array}$ & DB00207 & [44] \\
\hline Chloroquine & & OXPHOS & Inhibits the autophagy pathway & DB00608 & [45] \\
\hline
\end{tabular}


Table 1. Cont.

\begin{tabular}{|c|c|c|c|c|c|}
\hline Drug & Structure & Pathway in Volved & Mechanism of Action & Accession Number & References \\
\hline Aspirin & & ALDH1, NF-kB & Blocks prostaglandin synthesis & DB00945 & [46] \\
\hline Disulfiram & & WNT, $\beta$-catenin and NF-кB & $\begin{array}{l}\text { Induce apoptosis in cancer } \\
\text { stem cells }\end{array}$ & DB00822 & {$[47]$} \\
\hline Aprepitant & & WNT & $\begin{array}{c}\text { Inhibit emesis } \\
\text { induced by cytotoxic } \\
\text { chemotherapeutic agents }\end{array}$ & DB00673 & [48] \\
\hline Atovaquone & & HER2/ $\beta$-catenin & $\begin{array}{l}\text { Antiprotozoal, antimicrobial and } \\
\text { antipneumocystis activity }\end{array}$ & DB01117 & [49] \\
\hline AZD8055 & & mTOR & $\begin{array}{l}\text { Activation of epidermal growth } \\
\text { factor receptor }\end{array}$ & DB12774 & {$[50]$} \\
\hline
\end{tabular}


Table 1. Cont.

\begin{tabular}{|c|c|c|c|c|c|}
\hline Drug & Structure & Pathway in Volved & Mechanism of Action & Accession Number & References \\
\hline Crocetinic acid & & Hedgehog & $\begin{array}{l}\text { Inhibited epidermal growth } \\
\text { factor receptor and Akt } \\
\text { phosphorylation }\end{array}$ & NA & [51] \\
\hline GANT-61 & & Hedgehog & $\begin{array}{l}\text { Inhibited cell viability. } \\
\text { protects autophagy }\end{array}$ & NA & [52] \\
\hline Ketamine & & WNT & $\begin{array}{l}\text { Inhibiting proliferation, } \\
\text { invasion, and migration }\end{array}$ & DB01221 & [53] \\
\hline Metformin & & mTOR, PI3K/Akt & Antineoplastic activity & DB00331 & [54] \\
\hline Quinomycin A & & Notch & Suppresses CSCs growth & DB15582 & [55] \\
\hline
\end{tabular}


Table 1. Cont.

\begin{tabular}{|c|c|c|c|c|c|}
\hline Drug & Structure & Pathway in Volved & Mechanism of Action & Accession Number & References \\
\hline Rapamycin & & mTOR & Reduced the viability of CSCs & DB00877 & [56] \\
\hline RO-4929097 & & Notch & $\begin{array}{l}\text { Suppresses the tumor initiating } \\
\text { potential of cancer cells }\end{array}$ & DB11870 & [57] \\
\hline Sanguinarine & & Hedgehog & Inhibits the growth of CSCs & NA & {$[58]$} \\
\hline Tigecycline & & OXPHOS & $\begin{array}{l}\text { Inhibits cell proliferation, } \\
\text { migration and invasion }\end{array}$ & DB00560 & [59] \\
\hline $\begin{array}{l}\text { 5-FU (Fluorouracil } \\
\text { Injection) }\end{array}$ & & Antineoplastic antimetabolite & $\begin{array}{l}\text { Inhibition of the formation of } \\
\text { thymidylate from uracil }\end{array}$ & DB00544 & {$[60]$} \\
\hline
\end{tabular}


Table 1. Cont.

\begin{tabular}{|c|c|c|c|c|c|}
\hline Drug & Structure & Pathway in Volved & Mechanism of Action & Accession Number & References \\
\hline Mitomycin & & Antineoplastic antibiotic & $\begin{array}{l}\text { Alkylating agent which inhibits } \\
\text { DNA synthesis }\end{array}$ & DB00305 & [60] \\
\hline Abraxane/Paclitaxel & & Microtubule associated protein & $\begin{array}{l}\text { Stabilizes microtubules by } \\
\text { preventing depolymerization }\end{array}$ & DB01229 & [61] \\
\hline $\begin{array}{l}\text { Gemcitabine } \\
\text { Hydrochlo- } \\
\text { ride/Gemzar }\end{array}$ & $\mathrm{Cl}$ & Antineoplastic anti-metabolite & Inhibits thymidylate synthetase & DB00441 & [61] \\
\hline
\end{tabular}


Table 1. Cont.

\begin{tabular}{|c|c|c|c|c|c|}
\hline Drug & Structure & Pathway in Volved & Mechanism of Action & Accession Number & References \\
\hline Afinitor/Everolimus & & mTOR inhibition & Immunosuppressant & DB01590 & {$[62]$} \\
\hline $\begin{array}{c}\text { Erlotinib } \\
\text { Hydrochlo- } \\
\text { ride/Tarceva }\end{array}$ & & $\begin{array}{l}\text { Epidermal growth factor } \\
\text { receptor (EGFR) }\end{array}$ & $\begin{array}{l}\text { Inhibits the intracellular } \\
\text { phosphorylation of } \\
\text { tyrosine kinase }\end{array}$ & DB00530 & [63] \\
\hline
\end{tabular}


Table 1. Cont.

\begin{tabular}{|c|c|c|c|c|c|}
\hline Drug & Structure & Pathway in Volved & Mechanism of Action & Accession Number & References \\
\hline Lynparza/Olaparib & & $\begin{array}{l}\text { Poly (ADP-ribose) polymerase } \\
\text { (PARP) inhibitor }\end{array}$ & Inhibit growth of tumor cells & DB09074 & {$[64]$} \\
\hline Onivyde/Irinotecan & & Antineoplastic enzyme inhibitor & $\begin{array}{l}\text { Inhibits the action of } \\
\text { topoisomerase I }\end{array}$ & DB00762 & {$[65]$} \\
\hline $\begin{array}{c}\text { Sunitinib } \\
\text { Malate/Sutent }\end{array}$ & & $\begin{array}{l}\text { Multi-targeted receptor tyrosine } \\
\text { kinase (RTK) inhibitor }\end{array}$ & $\begin{array}{l}\text { Inhibits cellular signaling by } \\
\text { targeting multiple RTKs }\end{array}$ & DB01268 & {$[66]$} \\
\hline
\end{tabular}


Table 2. Drug combinations used in pancreatic cancer.

\begin{tabular}{|c|c|c|c|}
\hline Drug & Accession Number & Function & Mechanism of Action \\
\hline \multicolumn{4}{|l|}{ FOLFIRINOX } \\
\hline FOL: Folinic acid/Leucovorin & DB00650 & Antidote & $\begin{array}{c}\text { Enhances the effects of } \\
\text { 5-fluorouracil }\end{array}$ \\
\hline F: Fluorouracil & DB00544 & $\begin{array}{l}\text { Pyrimidine analog and } \\
\text { antimetabolite }\end{array}$ & Inhibit DNA synthesis \\
\hline IRIN: Irinotecan/Camptosar & DB00762 & Topoisomerase inhibitor & $\begin{array}{l}\text { Prevents DNA from uncoiling } \\
\text { and duplicating }\end{array}$ \\
\hline OX: Oxaliplatin/Eloxatin & DB00526 & $\begin{array}{l}\text { Platinum-based } \\
\text { antineoplastic agent }\end{array}$ & Inhibits DNA repair and synthesis \\
\hline \multicolumn{4}{|l|}{$\begin{array}{l}\text { GEMCITABINE- } \\
\text { OXALIPLATIN }\end{array}$} \\
\hline Gemcitabine & DB00441 & Antineoplastic anti-metabolite & Inhibits thymidylate synthetase \\
\hline Oxaliplatin & DB00526 & $\begin{array}{l}\text { Platinum-based } \\
\text { antineoplastic agent }\end{array}$ & Inhibits DNA repair and synthesis \\
\hline \multicolumn{4}{|l|}{ GEMCITABINE-CISPLATIN } \\
\hline Gemcitabine & DB00441 & Antineoplastic anti-metabolite & Inhibits thymidylate Synthetase \\
\hline Cisplatin & DB00515 & Antineoplastic & Alkylating agents \\
\hline \multicolumn{4}{|l|}{ OFF } \\
\hline O: Oxaliplatin & DB00526 & $\begin{array}{c}\text { Platinum-based } \\
\text { antineoplastic agent }\end{array}$ & Inhibits DNA repair and synthesis \\
\hline F: Fluorouracil & DB00544 & Antineoplastic antimetabolite & $\begin{array}{l}\text { Inhibition of the formation of } \\
\text { thymidylate from uracil }\end{array}$ \\
\hline F: Folinic Acid/Leucovorin & DB00650 & Antidote & $\begin{array}{c}\text { Enhances the effects of } \\
\text { 5-fluorouracil }\end{array}$ \\
\hline
\end{tabular}

\section{Signaling Pathways Involved in PCSCs}

Different signaling pathways: PI3K/AKT [67,68], JNK [69], MEK/ERK [70], nuclear factor kappaB (NF-kB) [71], TGF- $\beta$ [72], WNT [73,74], and Hedgehog [75,76] are known to crosstalk with Notch signaling pathway or with each other in the progression of pancreatic CSCs [77-79], because of their crucial role in production and differentiation of pancreatic cells $[80,81]$. It is therefore believed that the interaction between these signaling pathways and Notch signaling pathway can play an important role in the development of pancreatic tumors [78]. In CSCs and the EMT process of pancreatic cancer, signaling pathways are altered and are involved in CSC self-renewal, tumor formation, metastasis, invasion, and resistance to chemo-radiation [82]. There are various studies in which researchers have investigated new treatment strategies to control these pathways in order to cure cancer $[77,83]$.

\subsection{Notch Signaling Pathway}

Notch signaling is one of the conserved signaling pathways accountable for cell-to-cell direct contact. The pathway of notch signaling is associated with pancreatic cell's survival, proliferation, apoptosis, development, differentiation, and can promote EMT. It is essential for various aspects of cancer biology: angiogenesis, CSCs, and tumor immunity [84]. Notch signaling pathways have been shown to promote vascular endothelial growth factor (VEGF) and cellular migration in pancreatic cancer cells by activating NF- $\mathrm{KB}$ [85]. The Notch pathways consist of five canonical ligands (Delta-like ligand 1 (DLL1), DLL3 and DLL4, and 
Jagged1 and 2) and four single-pass transmembrane receptors (Notch1 to Notch4) [86,87]. Different ligands and receptors of Notch are expressed by various types of tumor. Notch signaling causes pancreatic Nestin ${ }^{+}$precursor cells accumulation and extend the ductal epithelium. Notch is associated with pancreatic cancer cell development by retaining epithelial cells in a progenitor state. Tumor cells exhibit Notch signaling over-expression, high Notch-1, and Notch-2 levels, while a poor expression of Notch signaling related factors is exhibited by the normal pancreas. Midkine is a heparin binding growth factor, interacts with Notch2 in chemo-resistant PDAC, leads to increased expression of EMT and Notch pathway markers [88]. Studies of prostate cancer have shown increased marker expression of EMT and Notch1, including vimentin, N-cadherin, ZEB1 (Zinc-finger E-box binding homeobox), NF- $\mathrm{kB}$, and PDGF-D in tumor cells [89]. In particular, two members of the Notch signaling pathway are involved in pancreatic cell development and carcinogenesis [90]. Few studies have shown increased Notch2 expression in PDAC rather than Notch1; Notch1 is activated during early pancreatic development, while Notch2 is mainly concerned with the branching of the ductal epithelium [91]. Furthermore, researchers have identified Notch1 and Notch2 as the main determinant in pancreatic carcinogenesis [92,93]. Overexpression of Notch2 and Jagged1 has been shown in gemcitabine resistant pancreatic cancer cells, whereas Notch1 is a crucial downstream mediator of Kirsten rat sarcoma viral oncogene homology (KRAS), and control tumor sphere formation of pancreatic cells [94,95]. In pancreatic cancer, the oncogenic KRAS mutation is the main factor, provides irreversible protein KRAS induction, and functions as a signaling molecule to trigger different transcription factors and intracellular signaling pathways related to cell proliferation, differentiation, migration, and survival [96]. High expression of Notch-1 and Jagged-1 has been associated with poor prognosis and patient survival in primary breast cancers [97]. DLL4 ligand overexpression in pancreatic cancer cells stimulates OCT4 and NANOG (pluripotency markers) expression, thereby increasing the number of CSCs [98]. Notch pathway activation is mainly responsible for the resistance of PCSCs to chemotherapy, yet the precise mechanism behind this remains poorly understood $[95,99]$. However, several pieces of evidence have shown that the Notch signaling pathway plays an important role in the development of pancreatic cancer, like supporting KRAS, and for the transformation of normal cells to tumor stem cells [90]. The Notch signaling pathway is triggered by several enzyme complexes, including $\gamma$-secretase complexes following Notch-ligand interaction and three consecutive proteolytic cleavages [84]. Notch1 inhibition induces increased the rate of apoptosis, migration, and intrusive properties of pancreatic cancer cells with $\gamma$-secretase inhibitors [100]. In 2018, Song et al. performed an experiment to evaluate the expression and possible therapeutic importance of Notch ligands and receptors in human PDAC [101]. The increased expression of Notch1 and 3 in PDAC tissues was observed, suggesting that both of these receptors may play an important role in the development of pancreatic cancer, and researchers have therefore referred to these receptors as oncogenes. On the other hand, the level of Notch 2 and 4 receptor and Notch ligands (DLL-1, 3, and 4) has been found to be decreased and increased, respectively [101]. Furthermore, Notch signaling pathway inhibition in the treatment of pancreatic cancer can be very attractive since there is no evidence disagreeing that Notch signaling plays a crucial role in pancreatic cell development, and addressing Notch as a remedy for pancreatic cancer might inhibit CSCs resistance to chemotherapy [102,103].

\subsection{Hedgehog Signaling Pathway}

The hedgehog signaling pathway is associated with the development, proliferation, and differentiation of embryonic cells [104] and also regulates healthy and malignant stem cells [105]. Researchers have shown that the Hedgehog pathway normally dormant in adult organs while remains active in cancer cells, where extracellular matrix production, myofibroblast differentiation, and stromal hyperplasia can be increased, allowing the EMT process in cancer cells $[75,106,107]$. The activation of the Canonical Hedgehog signaling pathway is represented by the Hh ligands' (Sonic (SHH), Indian (IHH), and Desert (DHH)) 
interaction with the receptor Patched1 $[108,109]$. In $70 \%$ of pancreatic cancer tissue, overexpression of SHH suggests that Hedgehog signaling may be responsible for pancreatic cancer [110]. PANC-1 (pancreatic cancer cell line) studies have shown that smoothened suppression inhibits Hedgehog signaling, which can reverse EMT and induces apoptosis by inhibition of PI3K/AKT, and prevents pancreatic cancer cell invasion [111]. The hedgehog signaling pathway is a crucial objective for the development of chemotherapy [112]. The progression of many forms of cancer, including pancreatic cancer, is characterized by abnormal Hedgehog signaling pathway activity [113]. The survival of CSCs has been impaired by targeting Notch and Hedgehog signaling together, which indicates that these two pathways should be targeted at once in order to successfully eradicate certain forms of cancer [114]. Schreck et al. found that Notch suppresses Hedgehog directly by Gli1 transcription inhibition mediated by Hes1 [115]. Gli1 and Gli2 components of the Hedgehog are positively capable of controlling Hes1 regardless of the Notch pathway [116]. Concomitantly targeting both pathways could be more efficient in curing cancer. Notch pathway's downregulation contributes to the inhibition of pancreatic cell growth and apoptosis, while the inhibition of Hedgehog leads to advancement in drug delivery to tumors [117]. The cancer stem cell maintenance, tumor-stroma cross-talk, and chemo-resistance could also be affected by interactions between Hedgehog and other signaling pathways. Mohelnikova et al. did not found any strong correlation between Hedgehog expression profile and KRAS mutation status in PDAC patients [118], regardless of previous PDAC studies [119]. Taxoid involvement with a dysregulated Hedgehog signaling pathway in patients with PDAC could have significant therapeutic benefits. New-generation taxoids can abrogate the overexpression of Hedgehog in pancreatic cancer [118]. Molecular interaction between WNT / $\beta$-catenin, Notch, TGF- $\beta$, and hedgehog indicates that during oncogenesis, two or more pathways crosstalk with each other. Thus in order to target different signaling pathways at once, a combination of novel inhibitors and traditional anti-tumor therapy are required to increase the effectiveness.

\subsection{WNT Signaling Pathway}

A significant embryonic signaling pathway for the morphogenesis, proliferation, and differentiation of various tissues, including the pancreas, is the WNT signaling pathway [120]. The WNT signaling consists of three main pathways: the canonical WNT pathway, non-canonical planar-cell polarity, and the non-canonical WNT calcium pathway [121]. Essentially, suppression of WNT signaling, along with Notch and Hedgehog signaling pathways, has led to the expansion of agents capable of inhibiting tumor invasiveness, metastasis, and carcinogenesis. In several forms of cancers, the WNT/ $\beta$-catenin pathway regulates the self-renewal, proliferation, apoptosis, migration, and differentiation of stem cells [122]. Chemo-resistance in pancreatic cancer is also correlated with the impairment of the WNT/ $\beta$-catenin pathway [122]. Liu et al. suggested that initiated $\beta$-catenin may increase self-renewal capability, reduces differentiation rate, and develop epithelial cancers [123]. A common characteristic of several kinds of pancreatic cancer is the activation of WNT signaling. In unusual tumor forms: acinar cell carcinoma, strong pseudo-papillary neoplasm, and pancreatoblastoma; mutation in canonical WNT/ $\beta$-catenin components are generally observed [124]. WNT signaling is frequently triggered in PDAC, regardless of the lack of the normal phenomenon of mutations in pathway components. Sano et al. demonstrated that the activation of non-canonical signaling pathways contributes to the development of tumors [125]. CYR61 expression is triggered by activation of the WNT / $\beta$-catenin pathway, and CYR61 in response stimulates WNT/ $\beta$-catenin signaling (feedback mechanism). Thus, disruption of this process represents a potential opportunity for therapeutic treatment [125]. WNT signaling influences many aspects of pancreatic biology, and its activity are constantly increased during pancreatic carcinogenesis. In pancreatic cancer, activated WNT target genes and accumulation of $\beta$-catenin have been observed [126]. Both Notch and WNT signaling pathways are important pathways that control stem cell differentiation and proliferation [127]. The Notch signaling pathway 
encourages pancreatic lineage commitment and pancreatic progenitor cell differentiation, whereas WNT signaling controls the stem cell state [128,129]. The Notch pathway is regulated by WNT signaling through the negative influence of WNT on the activity of GSK3- $\beta$ mediated by Dishevelled-2. WNT and Notch signaling pathways seem to be interconnected; the Notch pathway functions as a negative controller $\beta$-catenin dependent pathway both in pancreas development and oncogenesis [73].

\section{Epithelial to Mesenchymal Transition}

The EMT seems to be a major factor in various natural biological processes, such as wound healing, embryogenesis, and cancer development. Evidence suggests that abnormal initiation of the EMT and developmental program leads to tumor initiation, metastasis, invasion, and therapeutic resistance $[94,130]$. EMT is a greatly harmonized process noticed when more or less epithelial features are lost by epithelial cells and embark on attaining mesenchymal cell characteristics, which is a crucial step during embryogenesis [131]. By stimulating multiple EMT transcription factors such as Twist, ZEB, Snail, and Slug; TGF- $\beta$, WNT, Notch, and Hedgehog signaling facilitated the conversion of epithelial cells into mesenchymal cells. In several cancer types, specific EMT signaling pathways such as Notch have been observed to be dysregulated, and activation of these signaling is often associated with poor clinical outcomes [132]. Dysregulation of TGF- $\beta$ and Notch pathways of EMT plays an essential role in cancer and cardiovascular diseases [133]. WNT pathway in EMT regulates the levels of GSK3- $\beta, \beta$-catenin, Snail, and other processes linked with tumor progression [134]. It has been shown that EMT plays a key role in cancer cell resistance to traditional chemotherapeutics, including gemcitabine, vincristine, oxaliplatin, and taxol [135]. Gemcitabine resistant PCSCs showed mesenchymal morphology with activation of Alpha-SMA, Nestin, vimentin, and fibronectin and downregulation of $\beta$ catenin and E-cadherin [132]. The above-discussed studies have proven that dysregulation of different signaling pathways involved in EMT is crucial in tumor progression.

\section{Role of Epigenetics}

The complex interaction between genomic, epigenomic, and signaling pathway alterations affect PDAC growth and progression [136]. It has been shown that the EMT leads to the malignant phenotype in PCSCs. Extensive research regarding genetics and patterns of genome-wide expression suggests that genetic alterations are important for the initiation and early development of PDAC. Epigenomic studies, however, have shown that epigenetic changes in cancer cells and tumor suppressor genes have affected tumor growth [137]. Epigenetic modifications are legacy modifications of DNA or chromatin structures that affect gene expression without altering the sequence of DNA [138]. Antagonism between stemness inhibiting micro-RNAs and ZEB1 has been shown to contribute to the EMT process for PCSCs [139]. Schmalhofer et al. have shown that ZEB1 promotes the EMT process by controlling the related protein binding domains such as the p300-P/CAF binding domain, Smad interaction domain, and C-terminal-binding protein interaction domain [140]. Moreover, ZEB1 stimulates EMT by blocking E-cadherin [141]. Moreover, Zhang et al. demonstrated the link between ZEB1 and epigenetic regulation of EMT [142]. The ZEB1 promotes the epigenetic silencing of E-cadherin through the incorporation of various E-cadherin promoter chromatin enzymes such as histone deacetylases, DNA methyltransferase, and ubiquitin ligase [142]. The drug resistance of PCSCs has also been shown to be associated with ZEB1 [143]. ZEB1 plays a crucial role in EMT during tumor carcinogenesis [144]. However, the clinical efficacy of ZEB1 for solid human tumors remains uncertain. In order to determine the prognostic importance of $Z E B 1$ in patients with solid tumors, Chen et al. conducted a meta-analysis to determine the prognostic importance of ZEB1 in patients with solid tumors [144]. The elevated ZEB1 expression indicates poor survival in solid tumor patients. This study suggested that ZEB1 could be a possible biomarker and potential therapeutic target for prognosis in solid human tumors [144]. 


\section{Role of G Protein-Coupled Receptor in Pancreatic Cancer}

The prospective of G protein-coupled receptors (GPCRs) in pancreatic adenocarcinoma and GPCR-targeted drugs as potential therapeutics for pancreatic cancer have been outlined in this section. The largest family of plasma membrane cell surface receptors is GPCRs (seven trans-membrane domain receptors), with $>800$ human members: $\sim 400$ are endoGPCRs that, in contrast to chemosensory GPCRs, respond to endogenous agonists (e.g., hormones and neurotransmitters). Being a family of cell surface receptors, EndoGPCRs are the largest family with targets for approved drugs, providing access from the extracellular environment. Signaling from GPCR affects different aspects of cancer like invasion, remolding, migration, etc. Functional aspects of GPCR have been established in cancers, including pancreatic cancer, both in the cells of cancer and tumor microenvironment. A wide variety of GPCRs are expressed by pancreatic adenocarcinoma tumor cells [145]. As the GPCRs are the largest drug target family, about $34 \%$ of all drugs approved by the Food and Drug Administration (FDA) targeted 108 members of GPCR [146]. In 2018, the worldwide sales of these drugs cost approximately 180 billion US dollars [146]. For the treatment of various diseases, GPCR targeted drugs have been used. GPCRs have been assessed as targets for about $50 \%$ of drugs available on the market due to their primary involvement in signaling pathways linked to many diseases, i.e., metabolic, immunological, mental, cardiovascular, sensory, inflammatory, and cancers. As GPCR play an important role in controlling signaling pathways involved in cancer, they are used as biomarkers for the early prognosis, and only a few receptors are represented by GPCR [147]. This is primarily due to drug resistance; receptor desensitization has been observed in experiments utilizing long and short-term exposure to GPCR-targeting drugs [147,148]. In order to develop new GPCR based therapy, more research is required on the downstream regulators and pharmaceutical potential of GPCRs, which can efficiently control cancer cell pathways. Additionally, most cancer forms, including PDAC, female sex is related to poor prevalence and better therapeutic results. The underlying mechanism behind this sex-based incidence was unclear. Regardless of the fact that PDAC lacks basic nuclear estrogen receptors, Natale et al. believed that estrogen signaling could be responsible for sex-based incidence [149]. They have used synthetic agonist G-1 (small molecule) that activates $G$ protein-coupled estrogen receptor (GPER), which have been used to inhibit PDAC by GPER estrogen receptors present on tumor cells. Subsequently, it contributed to PDAC proliferation inhibition, reduced PDL-1 (programmed death ligand-1), c-Myc, and increased immunogenicity of the cells [149]. Researchers found that the G-1 contributes to inhibition of melanoma, suggesting that GPER agonists could be helpful against a large range of cancers (cancers of the lung, adrenal gland, bone, colon, and skin etc.) with the exception of sex hormone related cancers $[149,150]$.

\section{Role of Cysteine in Pancreatic Cancer}

Another approach for PDAC is to target essential biological processes involved, especially in PDAC cells. Depletion of cysteine causes ferroptosis (programmed cell death dependent on iron and characterized by the accumulation of lipid peroxides) of pancreatic cancer cells [151]. Ferroptosis is a type of programmed cell death induced by the disastrous production of reactive oxygen species (ROS). In several tumor types, lipid ROS production is increased by oncogenic signaling pathways and is counterbalanced by amino acid cysteine derived metabolites; exogenous cysteine is imported by cystine/glutamate transporter (Xc- system). The $\mathrm{X}_{\mathrm{C}}$ - system inhibition has been shown to promote ferroptosis in many cancer cell lines; therefore, in pancreatic cancer, cysteine is required to inhibit ferroptosis [152]. PDAC cells circumvent the consequences of increased ROS production, which can be caused by mutational activation of KRAS, as one example by upregulating metabolic processes that yield cysteine-derived metabolites, such as glutathione, that reduce ROS levels. Hypothesizing that cysteine import would be a key to the survival of PDAC cells, Badgley et al. performed in vitro experiments using human PDAC cell lines, which confirmed that PDAC cells depend on cysteine import. Specifically, PDAC cells 
deprived of cysteine by various means (including inhibition of the cysteine importer system $\mathrm{X}_{\mathrm{c}-}$ underwent ferroptosis [153]. In the PDAC mouse model, deletion of the gene encoding a subunit of system Xc- (Slc7a11) in established tumors substantially increased median survival and even caused complete tumor regression in one mouse. Tumors in which Slc7a11 was deleted exhibited microscopic characteristics abnormal for PDAC tumors, including large lipid droplets and structurally defective mitochondria, and had increased expression of ferroptosis-related genes. Interestingly, although previous work found that cysteine's role in ferroptosis was related to the synthesis of glutathione, inhibition of glutathione biosynthesis alone in human PDAC cell lines did not increase lipid ROS levels or cause ferroptosis. Instead, a reduction in levels of coenzyme A, also synthesized from cysteine, cooperated with glutathione loss to induce ferroptosis [153]. Notably, in a mouse model of PDAC, treatment with cystinase, which degrades cysteine, caused tumor stabilization or regression in all mice. Tumors from these mice exhibited the characteristic signs of ferroptosis observed with the $\mathrm{Xc}^{-}$system (Slc7a11) deletion, including abnormally large lipid droplets and mitochondrial aberrations. Collectively, these results provide further evidence that PDAC is dependent on cysteine metabolism to prevent ROS-induced ferroptosis and suggest that cysteine depletion may be a useful clinical strategy [153]. As cysteine import is related to the pancreatic cancer cell's survival, researchers proposed that cancer growth can be inhibited by selectively targeting cysteine. Researchers observed that cystine starvation leads to the reduction of glutathione in cells, and vitamin E can be used to revive cysteine starvation-induced cell death, thus suggesting the role of induced oxidative cell death in this case [154]. Cysteine is required for glutathione production inside the cancer cell, which it uses as a defense [153]. Chemotherapy used without sulfasalazine ( $\mathrm{Xc}^{-}$system inhibitor) is ineffective in PDAC. Sulfasalazine, an old cheap off-patent drug, is used alongside artesunate and intravenous vitamin $C$, which at a high dose, produces hydrogen peroxide free radicals, a cocktail that is also combined with iron to effectively induce ferroptosis. Researchers have demonstrated that cysteinase, a new drug compound, can starve pancreatic cells of cysteine supply, causing ferroptosis [153].

\section{Role of Pyruvate Kinase M2}

Under aerobic and anaerobic environments, differentiated cells prefer oxidative phosphorylation and anaerobic glycolysis, respectively [155]. In comparison, even in the presence of oxygen (the Warburg effect), proliferative tissue and cancer cells appear to intake a large quantity of glucose to generate lactate through glycolysis. The Warburg effect is mediated by the pyruvate kinase M2 (PKM2) isoform [156]. Conversion of phosphoenol-pyruvate and adenosine diphosphate into pyruvate and adenosine triphosphate is catalyzed by pyruvate kinases. There are four isoforms of Pyruvate kinase (L, R, M1, and M2: PKL is present in the liver, PKR is expressed by red blood cells, PKM1 present in most differentiated tissues, and PKM2 expressed in embryonic and cancer cells [156,157]. PKM2 is highly expressed in different forms of human cancer, including pancreatic cancer $[158,159]$. As earlier discussed, PDAC cells change their metabolism from mitochondrial to glycolysis, which fuels the plasma membrane calcium pump (PMCA), ultimately prevents $\mathrm{Ca}^{2+}$ induced cell death; PDAC has low survival and few possible treatments [160].

In PDAC cells, glycolytic ATP production inhibition promotes cytotoxic $\mathrm{Ca}^{2+}$ accumulation and cell death, as researchers showed that increased glycolytic rate is important for fueling the ATP dependent PMCA [161], PMCA's dependency on glycolytic ATP seems to be a possible therapeutic option. Identifying the molecular mechanism behind the dependency of PMCA on glycolytic ATP could reveal novel therapeutic goals for the development of effective drugs. PKM2 is a major glycolytic enzyme-producing oncogenic ATP, especially over-expressed in pancreatic cancer [162,163]. Furthermore, effective and selective inhibitor of PKM2 is shikonin, anti-inflammatory, antimicrobial, and anti-cancer effects of shikonin have been reported [164]. In PDAC, shikonin is a valuable method for investigating the supply of PKM2-mediated ATP to PMCA. For cell survival, a functional relationship is important between PMCA and PKM2. Shikonin reduces cell viability, proliferation, PDAC 
migration and induces cell death [160]. Researchers demonstrated that elevated expression of PKM2 is related to poor recovery in human PDAC. The PKM2 downregulation leads to lower intracellular metabolites level and glycolytic activities [162]. Additionally, various cancer properties in pancreatic cancer cells were suppressed by shikonin. Recently, James et al. performed a study where they have cut off the supply of glycolytic ATP to the pancreatic cancer cells PMCA; it would be comparatively extra effective in cancer cells than non-cancerous cells [160]. In metabolic activities, as well as in PDAC cell malignancy, PKM2 plays a significant role.

\section{Repurposed Drugs for CSCs}

In this section, we discussed some non-cancer targeted drugs with anti-cancer effects against CSCs that can be used to treat PDAC. These drugs function through various mechanisms of action, along with the inhibition of certain significant pathways involved in PCSCs. Antibiotics are among the molecules that display extremely complex biological behaviors by interacting with the EMT and WNT pathways in breast CSCs [42]. Salinomycin has been shown to inhibit tumor growth and metastatic spread of PDAC in a genetically modified mouse model [165]. Nigericin has been shown to inhibit EMT, increase the expression of E-cadherin, and induce cell cycle arrest of CSCs that contribute to the reduction in cancer cell invasion and metastasis $[43,166]$. Furthermore, azithromycin has been shown to increase the overall survival rate in cancer patients by preventing the development of tumors in PDAC and other cancers [44]. Moreover, certain anti-malarial agents such as chloroquine have been shown to have important effects on PCSCs by inhibiting the Hedgehog pathways and CXCR4 [45]. Aspirin has the potential to be an effective adjuvant cancer therapy and might be a promising candidate for eradicating PCSCs in PDAC [46]. The phase III trial acknowledged the significant effect of aspirin as an alternative therapy to avoid disease recurrence [46]. Metformin showed a significant potential for pancreatic cancer chemoprevention through decreased PCSC markers and inhibition of the mechanistic target of rapamycin (mTOR), extracellular signal-regulated kinases (ERK), phosphorylated extracellular signal-regulated kinases (pErk), and insulin-like growth factor 1 (IGF-1) in a PDAC mouse model [167]. Another non-cancer related drug, disulfiram, is able to target PCSCs in PDAC by inhibiting ERK, proteasome, and NF- $\mathrm{KB}$ signaling pathway when used alone or in combination with chemo-radiation [47]. Additionally, a phase II clinical study showed that the combination of disulfiram and chemotherapy improved survival in newly diagnosed lung cancer patients [168]. The above discussed studies showed that the repurposing of existing compounds to target PCSCs could also be a potential approach to overcome PDAC.

\section{Immunotherapy for Pancreatic Cancer}

Several targeted strategies, including new stromal modulation, immunotherapeutic approaches, and targeting main signaling pathway effectors, are in progress, along with the development of novel cytotoxic therapeutic strategies. The stroma encompasses approximately $90 \%$ of the tumor mass, which promotes the progression of fibrosis and immunosuppression [169]. In addition to facilitating tumor development, the PDAC stroma has been shown to attenuate the delivery of antitumor treatments, inactivation of cytotoxic $\mathrm{CD}^{+} \mathrm{T}$ cells, and increasing the number of immunosuppressive cells [170,171]. During the progression of the disease, the number of pancreatic stellate cells and PDAC specific cancer associated fibroblasts increase abundantly [172]. These activated stellate cells promote tumor growth by reducing the migration of $\mathrm{CD} 8^{+} \mathrm{T}$ cells to juxtatumoral stromal compartments [173]. Stellate cells also stimulate $\mathrm{T}$ cell anergy and apoptosis induced by galectin-1, resulting in evasion of immune surveillance by the cancer cells $[173,174]$.

Furthermore, B lymphocytes contribute actively to PDAC fibrogenesis by activation and differentiation of cancer associated fibroblasts [175]. Minici et al. reviewed the immunological mechanisms that promote and inhibit the anti-tumor immunity of B cells. B cells can restrict tumor growth through phagocytosis by macrophages, facilitating tumor 
killing by NK cells, generating tumor-reactive antibodies, and the priming of $\mathrm{CD} 4^{+}$and $\mathrm{CD} 8^{+} \mathrm{T}$ cells [176]. B cells can facilitate tumor growth through the production of autoantibodies and tumor growth factors [176]. Further, targeting particular B cell subtypes can be beneficial for the treatment of cancer as the activities of Th1, and CD8 ${ }^{+}$cytolytic $\mathrm{T}$ cells can be directly and indirectly inhibited by regulatory B cells.

Presently, many clinical trials are trying to evaluate the efficiency of immunotherapeutic approaches in PDAC, including cancer vaccination [177], immune checkpoint inhibitors [178], monoclonal antibodies, adoptive cell transfer [179], chemo-radiotherapy or other molecularly focused agents, and combinations with other immunotherapeutic agents or immune modulators, though none of these studies have demonstrated improvements in practice. Activating a patient's T cells is the key basis of cancer immunotherapy in order to destroy tumor cells. Furthermore, important steps of immunotherapy are defined as follows: reduction in tumor-specific cells presenting antigen, $\mathrm{T}$ cell activation, $\mathrm{T}$ cells infiltration into tumors, cancer cell recognition by $\mathrm{T}$ cells, and cancer cell elimination [180]. AntiCTLA-4 (Ipilimumab) and anti-PD-1/anti-PDL-1 (Nivolumab/Pembrolizumab) agents have shown promising results in the activation of $\mathrm{T}$ cells and offer an efficient tumor immunotherapy strategy [181]. Despite showing Powerful outcomes of some malignancies, most of them in phase I and II clinical studies have not shown any clinical effectiveness in PDAC [182]. The immunosuppressive activity of CTL-4 results in the reduction of T effector cell activation and elevation in the activity of T regulatory cells [183]. The programmed cell death protein 1 (PD-1) is present largely on $\mathrm{T}$ cells, tumor cells, and tumor infiltrating lymphocytes [6]. The binding of PD-1 (Programmed death-ligand, PDL-1/PDL-2) leads to a reduction in $\mathrm{T}$ cell proliferation and secretion of antitumor cytokines [6].

A varied range of clinical trials (Table 3) on pancreatic cancer based on cytotoxic chemotherapy, vaccine-associated checkpoint inhibitors, immune checkpoint monotherapy, dual checkpoint combination therapy, and using other inhibitory agents have been completed or are presently ongoing. These clinical trials followed several therapeutic techniques:

1. Monotherapy includes the administration of several PD-1(MEDI4736, MPDL3280A, and pembrolizumab,) and CTL-4 (tremelimumab and ipilimumab) inhibitors and inhibition of double checkpoints: either by a combination of the above mentioned inhibitors or with other agents, such as anti-CCR-5 (mogamulizumab) [184].

2. Combination of chemotherapeutic agents and immune checkpoint inhibitors: PD$1 /$ CTL4 inhibitors leads to the activation of T cell that is efficient for immunotherapy. When PD-1/CTL4 inhibitors combined with commonly used chemotherapeutic agents such as Nab-paclitaxel, gemcitabine, carboplatin, and FOLFOX improved overall survival [47]. Remarkably, therapeutic procedures using a combination of immune checkpoint inhibitors with radiotherapy or chemotherapy have shown significant outcomes [185,186].

3. Vaccination therapy is founded on the basis of the distribution of tumor antigens to antigen presenting cells (APCs), followed by induction of an organized immune response. Cancer specific DNA mutations produce new antigens, which, in turn, results in a unique sequence of the peptide. Variety of vaccines for pancreatic cancer treatment includes whole-cell vaccines, dendritic-cell based vaccines, peptide and DNA vaccines, telomerase peptide vaccines, Ras peptide vaccines, and survivintargeted vaccines [187]; however, regardless of the enhanced immune system, showed poor clinical results. GVAX is an allogeneic irradiated whole-cell tumor vaccine genetically modified for the secretion of granulocyte macrophage colony stimulating factor and promotes cytolytic action against tumors, the most widely studied vaccine for pancreatic cancer [188]. Furthermore, the clinical studies when GVAX is applied in combination with 5-Fluorouracil/cyclophosphamide based chemotherapy have shown the same results regarding disease-free and median survival as that of GVAX applied alone [189]. On the other hand, when the above mentioned ipilimumab 
(immune checkpoint inhibitor) is applied in combination with GVAX, it leads to better survival [190].

4. Adoptive T cell immunotherapy is based on the modification of autologous $\mathrm{T}$ cells, which stimulates the immune response against the tumor. The patients receiving mesothelin-targeting chimeric antigen receptor- $\mathrm{T}$ (CAR) cells have shown overexpression of a membrane antigen in pancreatic cancer, exhibited adequate patience but unsuccessful in showing good results [191]. Along with mesothelin, other cancerassociated antigens are being studied alone or in combination with chemotherapy as potential targets of CAR-T cells based therapy [191].

5. Immune modulating agents that target the microenvironment of the pancreas can also exert extensive antitumor activity. Anti-CD40 agonistic antibodies used in combination with gemcitabine in PDAC patients showed significant results [192]. PDAC patients treated with a CCR2 inhibitor (PF-04136309) exhibited fractional response and constant tumor when used in combination with FOLFIRINOX [193]. Several chemokine receptor molecules are under examination in clinical trials against PDAC. 
Table 3. Clinical trials of novel agents for PDAC and other pancreatic cancers.

\begin{tabular}{|c|c|c|c|c|c|c|c|}
\hline Pathological Condition & Enrolled Patients & Intervention & National Clinical Trial Number & Outcome Measures & Phase & Status & Result \\
\hline Neoplasms, Pancreas & 40 & Cancer stem cell vaccine & NCT02074046 & $\begin{array}{l}\text { Determine the safety of } \\
\text { immunization }\end{array}$ & Phase $1 / 2$ & Completed & $\begin{array}{l}\text { CTLs harvested from } \\
\text { CSC-vaccinated hosts were } \\
\text { capable of killing CSCs } \\
\text { in vitro }\end{array}$ \\
\hline $\begin{array}{c}\text { Metastatic } \\
\text { pancreatic cancer }\end{array}$ & 98 & $\begin{array}{l}\text { Gemcitabine, Nab-Paclitaxel, } \\
\text { GDC-0449 }\end{array}$ & NCT01088815 & $\begin{array}{l}\text { Progression free survival, } \\
\text { safety of combination therapy }\end{array}$ & Phase 2 & Completed & $\begin{array}{c}\text { Median progression-free } \\
\text { survival and overall survival } \\
\text { were } 5.42 \text { months and } \\
9.79 \text { months, respectively }\end{array}$ \\
\hline $\begin{array}{l}\text { Metastatic Pancreatic } \\
\text { Ductal Adenocarcinoma }\end{array}$ & 65 & $\begin{array}{l}\text { MEDI4736 Monotherapy, } \\
\text { Tremelimumab + MEDI4736 }\end{array}$ & NCT02558894 & $\begin{array}{l}\text { Response Rate, Overall } \\
\text { survival, progression } \\
\text { free survival, }\end{array}$ & Phase 2 & Completed & $\begin{array}{l}\text { Monotherapy reflected a } \\
\text { population of patients with } \\
\text { mPDAC who had poor } \\
\text { prognoses and rapidly } \\
\text { progressing disease }\end{array}$ \\
\hline $\begin{array}{l}\text { Second-line, third-line } \\
\text { and Greater Metastatic } \\
\text { Pancreatic Cancer }\end{array}$ & 303 & $\begin{array}{l}\text { GVAX Pancreas Vaccine, } \\
\text { CRS-207, Chemotherapy, } \\
\text { Cyclophosphamide }\end{array}$ & NCT02004262 & $\begin{array}{l}\text { Overall survival and } \\
\text { adverse effects }\end{array}$ & Phase 2 & Completed & $\begin{array}{c}\text { Median overall survival in the } \\
\text { primary cohort was } 3.7,5.4, \\
\text { and } 4.6 \text { months in arms A, B, } \\
\text { and C, respectively }\left(^{*}\right)\end{array}$ \\
\hline Pancreatic Neoplasm & 22 & $\begin{array}{l}\text { Monoclonal antibody, } \\
\text { chemotherapy }\end{array}$ & NCT00711191 & $\begin{array}{l}\text { Overall survival, progression } \\
\text { free survival, and time to } \\
\text { Progression }\end{array}$ & Phase 1 & Completed & $\begin{array}{l}\text { Well tolerated and associated } \\
\text { with antitumor activity in } \\
\text { patients with PDAC and } \\
\text { improved overall survival }\end{array}$ \\
\hline $\begin{array}{c}\text { Pancreatic } \\
\text { Adenocarcinoma } \\
\text { metastatic }\end{array}$ & 10 & $\begin{array}{c}\text { Melphalan, BCNU, Vitamin } \\
\text { B12, Vitamin C, and } \\
\text { autologous hematopoietic } \\
\text { stem cell }\end{array}$ & NCT04150042 & $\begin{array}{l}\text { Response rate in metastatic } \\
\text { lesions, overall survival, } \\
\text { progression free survival }\end{array}$ & Phase 1 & Ongoing & NA \\
\hline $\begin{array}{l}\text { Resectable pancreatic } \\
\text { adenocarcinoma }\end{array}$ & 42 & HIPEC-Gemcitabine & NCT03251365 & Morbidity, survival & Phase $2 / 3$ & Ongoing & NA \\
\hline
\end{tabular}


Table 3. Cont

\begin{tabular}{|c|c|c|c|c|c|c|c|}
\hline Pathological Condition & Enrolled Patients & Intervention & National Clinical Trial Number & Outcome Measures & Phase & Status & Result \\
\hline $\begin{array}{l}\text { PDAC, pancreatic } \\
\text { cancer, metastasis }\end{array}$ & 36 & $\begin{array}{l}\text { Ascorbic acid, Paclitaxel, } \\
\text { Cisplatin, Gemcitabine }\end{array}$ & NCT03410030 & $\begin{array}{c}\text { Determination of } \\
\text { preliminary efficacy }\end{array}$ & Phase $1 / 2$ & Ongoing & NA \\
\hline Pancreatic Cancer & 81 & $\begin{array}{c}\text { Pembrolizumab, Gemcitabine, } \\
\text { Docetaxel, Nab-paclitaxel, } \\
\text { Vinorelbine, Irinotecan, } \\
\text { Liposomal Doxorubicin }\end{array}$ & NCT02331251 & $\begin{array}{c}\text { Determine the recommended } \\
\text { phase } 2 \text { dose }\end{array}$ & Phase $1 / 2$ & Terminated & $\begin{array}{c}\text { The median progression-free } \\
\text { survival and overall survival } \\
\text { was } 9.1 \text { and } \\
15.0 \text { months, respectively }\end{array}$ \\
\hline Pancreatic Cancer & 15 & $\begin{array}{l}\text { Fludarabine, Anti-mesothelin } \\
\text { chimeric T cell receptor (CAR) } \\
\text { transduced peripheral blood } \\
\text { lymphocytes (PBL), } \\
\text { Cyclophosphamide, Aldesleukin }\end{array}$ & NCT01583686 & $\begin{array}{l}\text { Tumor regression response } \\
\text { and adverse effects }\end{array}$ & Phase $1 / 2$ & Terminated & $\begin{array}{l}\text { MORAb-009 (chimeric } \\
\text { monoclonal antibody) is } \\
\text { well tolerated }\end{array}$ \\
\hline $\begin{array}{c}\text { Pancreatic } \\
\text { adenocarcinoma }\end{array}$ & 10 & $\begin{array}{l}\text { Allogeneic hematopoietic } \\
\text { stem cell transplantation }\end{array}$ & NCT02207985 & Disease free survival & Phase $1 / 2$ & Unknown & $\begin{array}{l}\text { Patients are tumor-free for } \\
9 \text { years after diagnosis }\end{array}$ \\
\hline
\end{tabular}

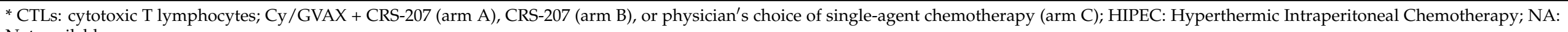

Not available. 


\section{Natural Killer Cell Therapy}

The primary immune cells that attack cancer cells and can be used as a therapeutic agent against pancreatic cancer are natural killer (NK) cells. NK cells are a heterogeneous subgroup of immune cells that express a wide variety of activators and inhibitors; hence they are able to attack and destroy the tumor cells directly without the necessity for major histocompatibility complex (MHC) specificity. NK cells have developed to counterpart $\mathrm{B}$ cells and $\mathrm{T}$ cells in host defense against carcinogens and other pathogens. If any carcinogenic mutation takes place, NK cells quickly start destroying neighboring cells. This feature is unique among immune cells, and their tendency to enhance antibody production, $\mathrm{T}$ cell, and B cell proliferation means NK cells likely play a significant role as anti-cancer therapy [194]. While tumors can evolve various mechanisms to counterattack endogenous NK cell attacks, in vitro or ex vivo activation, expansion and, genetic modification of NK cells can intensify their anti-tumor activity and allow resistance to be overwhelmed. Through specific mechanisms, which depend upon various sets of inhibitory and stimulatory receptors, are responsible for the tumor cell recognition via NK cells [194]. Some studies suggested the importance of NK cells in PDAC and their potential therapeutic effect [195]. PDAC significantly impair functions of NK cell by downregulating the ability of cytokines secretion and effector molecules. The tumor microenvironment also plays a key role in the reduction of NK cells cytotoxicity and stimulates immune suppression by different pathways. An antibody based NK cell homing protein called NK cell recruiting protein conjugated antibody (NRP-body) developed by researchers improved the efficiency of NK-cell based therapy in the treatment of PDAC [196]. The effect of NRP-body on the penetration of NK cells into primary and metastatic pancreatic cancer has been evaluated in PDAC murine model. NK-cell infiltration induced by CXCL16 via RhoA activation through the ERK signaling. NRP-body administration to pancreatic cancer mice model augmented the penetration of relocated NK cells into tumor cells, and the tumor load was decreased than that of control. NRP-body treated groups showed overall increased survival than that of other groups treated with NK cells alone [196]. Increased diffusion of NK cells into tumor tissues strengthened the response. Thus, for the treatment of pancreatic cancer, the combination of NRP-body with NK cell therapy is more beneficial than NK cells used alone.

\section{Discussion}

We have tried to deliberate nearly all of the most recent updates about several methods to treat pancreatic cancer, mainly PDAC. Pancreatic cancer, metastasis of tumor at the early stages and the dearth of efficacious treatment is the main reason behind the poor survival and the increased cancer death rate. Patients with pancreatic cancer have severe immune deregulation, marked by the proliferation of immunosuppressive cells and increased pro-inflammatory cytokines [197]. Various researchers have demonstrated that the EMT process and CSCs are mainly responsible for chemo-resistance and the metastatic potential of tumor cells $[39,198,199]$. CSCs development is based on genetic mutations in the signaling pathways, which leads to the transformation of undifferentiated and differentiated stem cells [200]. Due to the destructive tumor malignancy of PDAC, effective therapeutic approaches are still required, especially in order to disrupt its tumor microenvironment or EMT or to minimize its resistance to therapeutic agents. In the presence or absence of apparent metastatic disease, targeting molecules that directly facilitate infiltration and metastasis should be considered crucial in the treatment of PDAC and other pancreatic cancer $[85,201]$. Additionally, immunotherapy can be improved via NK cells as a result of their increased invasion of pancreatic cancer cells [196]. Conventional therapy in combination with CSC inhibitors may offer an effective approach for the treatment of pancreatic cancer [39]. Although the actual mechanism of action behind targeting PCSCs is poorly understood, stem cells, especially MSCs, can be an ideal candidate for the treatment of PDAC and pancreatic disorders due to their homing ability, anti-inflammatory, and immunomodulatory properties [26]. Moreover, PDAC patients treated with hematopoietic 
stem cells after pancreaticoduodenectomy (Whipple procedure) have shown no signs of disease recurrence (https: / / clinicaltrials.gov / ct2/ show /NCT02207985). MSCs offer a safer choice to cure PDAC as they do not exhibit immune rejection and teratoma formation [26]. Above mentioned studies suggest that MSCs transplantation will reduce the drug burden, inhibitor-associated side effects of pharmacotherapy and may prove to be useful for new drug testing.

\title{
14. Conclusions
}

PDAC remains a destructive disease with a poor survival rate and prognosis. This is due to the early stage tumor metastasis and the lack of any successful therapy. In the present review, we have summarized the current therapeutic strategies and the role of different factors like PCSCs, signaling pathways, and immunotherapy in PDAC. Recent advances in targeting PCSCs using effective drugs alone or in combination with MSCs have shown great potential in the treatment of PDAC by preventing CSCs development and proliferation. Different signaling pathways involved in PDAC are responsible for drug resistance that advocate the requirement of novel drugs to target these signaling pathways. Furthermore, sequencing and proteomics analysis is needed to identify the specific protein targets of signaling pathways involved in PCSCs to eliminate resistance against chemotherapy. Finally, an improved understanding of PCSCs related signaling pathways, identification of specific protein targets, and discovery of non-resistant drugs will guide successful PDAC therapies.

Author Contributions: G.T.-Conceptualization, Methodology, Writing—original draft; R.K.-Conceptualization, Formal analysis Methodology, Writing-reviewing and editing; S.-B.K.-Formal analysis Methodology; S.-Y.L.-Formal analysis, Methodology; S.-L.L.-Investigation, Supervision, Writing-reviewing and editing; G.-J.R.-Funding acquisition, Investigation, Supervision, Writingreviewing and editing. All authors have read and agreed to the published version of the manuscript.

Funding: This study was supported by a grant from the Stem Centric Co. Ltd., Korea.

Institutional Review Board Statement: Not applicable.

Informed Consent Statement: Not applicable.

Data Availability Statement: Not applicable.

Acknowledgments: Thanks to all our labmates, seniors, and families for their guidance and support.

Conflicts of Interest: The authors declare no conflict of interest.

\author{
Abbreviations \\ CSCs Cancer stem cells \\ EMT Epithelial mesenchymal transition \\ ESCs Embryonic stem cells \\ GPCR G protein-coupled receptor \\ GPER G protein-coupled estrogen receptor \\ MSCs Mesenchymal stem cells \\ NK cell Natural killer cells \\ PCSCs Pancreatic cancer stem cells \\ PDAC Pancreatic ductal adenocarcinoma \\ PKM2 Pyruvate kinase M2 \\ PMCA Plasma membrane calcium pump \\ ROS Reactive oxygen species \\ $\mathrm{SHH} \quad$ Sonic Hedgehog \\ $X_{C}-\quad$ Cystine/glutamate transporter \\ ZEB Zinc-finger E-box binding homeobox
}




\section{References}

1. Hong, S.; Won, Y.J.; Park, Y.R.; Jung, K.W.; Kong, H.J.; Lee, E.S. Cancer Statistics in Korea: Incidence, Mortality, Survival, and Prevalence in 2017. Cancer Res. Treat. Off. J. Kor. Cancer Assoc. 2020, 52, 335-350. [CrossRef]

2. Siegel, R.L.; Miller, K.D.; Jemal, A. Cancer statistics, 2020. CA Cancer J. Clin. 2020, 70, 7-30. [CrossRef]

3. Mathur, P.; Sathishkumar, K.; Chaturvedi, M.; Das, P.; Sudarshan, K.L.; Santhappan, S.; Nallasamy, V.; John, A.; Narasimhan, S.; Roselind, F.S. ICMR-NCDIR-NCRP Investigator Group. Cancer Statistics, 2020: Report From National Cancer Registry Programme, India. JCO Glob. Oncol. 2020, 6, 1063-1075. [CrossRef]

4. Ilic, M.; Ilic, I. Epidemiology of pancreatic cancer. World J. Gastroenterol. 2016, 22, 9694-9705. [CrossRef] [PubMed]

5. Bray, F.; Ferlay, J.; Soerjomataram, I.; Siegel, R.L.; Torre, L.A.; Jemal, A. Global cancer statistics 2018: GLOBOCAN estimates of incidence and mortality worldwide for 36 cancers in 185 countries. CA Cancer J. Clin. 2018, 68, 394-424. [CrossRef]

6. Sarantis, P.; Koustas, E.; Papadimitropoulou, A.; Papavassiliou, A.G.; Karamouzis, M.V. Pancreatic ductal adenocarcinoma: Treatment hurdles, tumor microenvironment and immunotherapy. World J. Gastrointest. Oncol. 2020, 12, 173-181. [CrossRef]

7. Ying, H.; Dey, P.; Yao, W.; Kimmelman, A.C.; Draetta, G.F.; Maitra, A.; DePinho, R.A. Genetics and biology of pancreatic ductal adenocarcinoma. Genes Dev. 2016, 30, 355-385. [CrossRef]

8. Hidalgo, M.; Cascinu, S.; Kleeff, J.; Labianca, R.; Löhr, J.M.; Neoptolemos, J.; Real, F.X.; Van Laethem, J.L.; Heinemann, V. Addressing the challenges of pancreatic cancer: Future directions for improving outcomes. Pancreatology 2015, 15, 8-18. [CrossRef] [PubMed]

9. Siegel, R.L.; Miller, K.D.; Jemal, A. Cancer Statistics, 2017. CA Cancer J. Clin. 2017, 67, 7-30. [CrossRef]

10. Zhou, J.; Enewold, L.; Stojadinovic, A.; Clifton, G.T.; Potter, J.F.; Peoples, G.E.; Zhu, K. Incidence rates of exocrine and endocrine pancreatic cancers in the United States. Cancer Causes Control. 2010, 21, 853-861. [CrossRef] [PubMed]

11. Bond-Smith, G.; Banga, N.; Hammond, T.M.; Imber, C.J. Pancreatic adenocarcinoma. BMJ 2012, 344, e2476. [CrossRef]

12. Orth, M.; Metzger, P.; Gerum, S.; Mayerle, J.; Schneider, G.; Belka, C.; Schnurr, M.; Lauber, K. Pancreatic ductal adenocarcinoma: Biological hallmarks, current status, and future perspectives of combined modality treatment approaches. Radiat. Oncol. 2019, 14, 1-20. [CrossRef]

13. Corbo, V.; Tortora, G.; Scarpa, A. Molecular pathology of pancreatic cancer: From bench-to-bedside translation. Curr. Drug Targ. 2012, 13, 744-752. [CrossRef] [PubMed]

14. Ghaneh, P.; Costello, E.; Neoptolemos, J.P. Biology and management of pancreatic cancer. Postgrad. Med. J. 2008, 84, 478-497. [CrossRef] [PubMed]

15. Porta, M.; Fabregat, X.; Malats, N.; Guarner, L.; Carrato, A.; de Miguel, A.; Ruiz, L.; Jariod, M.; Costafreda, S.; Coll, S.; et al. Exocrine pancreatic cancer: Symptoms at presentation and their relation to tumour site and stage. Clin. Transl. Oncol. 2005, 7, 189-197. [CrossRef] [PubMed]

16. De Souza, A.; Khawaja, K.I.; Masud, F.; Saif, M.W. Metformin and pancreatic cancer: Is there a role? Cancer Chemother. Pharmacol. 2016, 77, 235-242. [CrossRef]

17. Ben, Q.; Xu, M.; Ning, X.; Liu, J.; Hong, S.; Huang, W.; Zhang, H.; Li, Z. Diabetes mellitus and risk of pancreatic cancer: A meta-analysis of cohort studies. Eur. J. Cancer 2011, 47, 1928-1937. [CrossRef] [PubMed]

18. Wormann, S.M.; Algul, H. Risk factors and therapeutic targets in pancreatic cancer. Front. Oncol. 2013, 3, 282. [CrossRef]

19. Mayo, S.C.; Nathan, H.; Cameron, J.L.; Olino, K.; Edil, B.H.; Herman, J.M.; Hirose, K.; Schulick, R.D.; Choti, M.A.; Wolfgang, C.L.; et al. Conditional survival in patients with pancreatic ductal adenocarcinoma resected with curative intent. Cancer 2012, 118, 2674-2681. [CrossRef]

20. Kanojia, D.; Balyasnikova, I.V.; Morshed, R.A.; Frank, R.T.; Yu, D.; Zhang, L.; Spencer, D.A.; Kim, J.W.; Han, Y.; Yu, D.; et al. Neural stem cells secreting anti-her2 antibody improve survival in a preclinical model of her2 overexpressing breast cancer brain metastases. Stem Cells 2015, 33, 2985-2994. [CrossRef]

21. Wang, J.P.; Wu, C.Y.; Yeh, Y.C.; Shyr, Y.M.; Wu, Y.Y.; Kuo, C.Y.; Hung, Y.P.; Chen, M.H.; Lee, W.P.; Luo, J.C.; et al. Erlotinib is effective in pancreatic cancer with epidermal growth factor receptor mutations: A randomized, open-label, prospective trial. Oncotarget 2005, 6, 18162-18173. [CrossRef] [PubMed]

22. Li, J.; Ng, J.; Allendorf, J.; Saif, M.W. Locally advanced pancreatic adenocarcinoma: Are we making progress? In Proceedings of the 2011 ASCO Annual Meeting, Chicago, IL, USA, 3-7 June 2011; Volume 12, pp. 347-350. [CrossRef]

23. Carpelan-Holmstrom, M.; Nordling, S.; Pukkala, E.; Sankila, R.; Lüttges, J.; Klöppel, G.; Haglund, C. Does anyone survive pancreatic ductal adenocarcinoma? A nationwide study re-evaluating the data of the Finnish Cancer Registry. Gut 2005, 54, 385-387. [CrossRef] [PubMed]

24. Chopra, N.; Choudhury, S.; Bhargava, S.; Wajid, S.; Ganguly, N.K. Potentials of "stem cell-therapy" in pancreatic cancer: An update. Pancreatology 2019, 19, 1034-1042. [CrossRef]

25. Momin, E.N.; Vela, G.; Zaidi, H.A.; Qui nones-Hinojosa, A. The oncogenic potential of mesenchymal stem cells in the treatment of cancer: Directions for future research. Curr. Immunol. Rev. 2010, 6, 137-148. [CrossRef]

26. Ullah, I.; Subbarao, R.B.; Rho, G.J. Human mesenchymal stem cells-current trends and future prospective. Biosci. Rep. 2015, 35. [CrossRef] [PubMed]

27. Zachar, L.; Bacenkov, D.; Soltys, J.; Rosocha, J. Bioactive mediators associated with mesenchymal stem cells-mediated immunomodulation. J. Bone Stem Res. 2015, 1,6. 
28. Weiss, A.R.R.; Dahlke, M.H. Immunomodulation by mesenchymal stem cells (MSCs): Mechanisms of action of living, apoptotic, and dead MSCs. Front. Immunol. 2019, 10, 1191. [CrossRef]

29. Cousin, B.; Ravet, E.; Poglio, S.; De Toni, F.; Bertuzzi, M.; Lulka, H.; Touil, I.; André, M.; Grolleau, J.L.; Péron, J.M.; et al. Adult stromal cells derived from human adipose tissue provoke pancreatic cancer cell death both in vitro and in vivo. PLoS ONE 2009, 17, e6278. [CrossRef]

30. Doi, C.; Maurya, D.K.; Pyle, M.M.; Troyer, D.; Tamura, M. Cytotherapy with naive rat umbilical cord matrix stem cells significantly attenuates growth of murine pancreatic cancer cells and increases survival in syngeneic mice. Cytotherapy 2010, 12, 408-417. [CrossRef] [PubMed]

31. Brini, A.T.; Coccè, V.; Ferreira, L.M.J.; Giannasi, C.; Cossellu, G.; Giannì, A.B.; Angiero, F.; Bonomi, A.; Pascucci, L.; Falchetti, M.L.; et al. Cell-mediated drug delivery by gingival interdental papilla mesenchymal stromal cells (GinPa-MSCs) loaded with paclitaxel. Exp. Opin. Drug Deliv. 2016, 13, 789-798. [CrossRef]

32. Sun, Z.; Wang, S.; Zhao, R.C. The roles of mesenchymal stem cells in tumor inflammatory microenvironment. J. Hematol. Oncol. 2014, 7, 14. [CrossRef] [PubMed]

33. Chulpanova, D.S.; Kitaeva, K.V.; Tazetdinova, L.G.; James, V.; Rizvanov, A.A.; Solovyeva, V.V. Application of mesenchymal stem cells for therapeutic agent delivery in anti-tumor treatment. Front. Pharmacol. 2018, 9, 259. [CrossRef] [PubMed]

34. Valle, S.; Martin-Hijano, L.; Alcalá, S.; Alonso-Nocelo, M.; Sainz, B., Jr. The Ever-Evolving Concept of the Cancer Stem Cell in Pancreatic Cancer. Cancers 2018, 10, 33. [CrossRef]

35. Bonnet, D.; Dick, J.E. Human acute myeloid leukemia is organized as a hierarchy that originates from a primitive hematopoietic cell. Nat. Med. 1997, 3, 730-737. [CrossRef] [PubMed]

36. Plaks, V.; Kong, N.; Werb, Z. The cancer stem cell niche: How essential is the niche in regulating stemness of tumor cells? Cell Stem Cell 2015, 16, 225-238. [CrossRef] [PubMed]

37. O'Brien-Ball, C.; Biddle, A. Reprogramming to developmental plasticity in cancer stem cells. Dev. Biol. 2017, 430, 266-274. [CrossRef]

38. Rao, C.V.; Mohammed, A. New insights into pancreatic cancer stem cells. World J. Stem Cells 2015, 7, 547-555. [CrossRef]

39. Ercan, G.; Karlitepe, A.; Ozpolat, B. Pancreatic Cancer Stem Cells and Therapeutic Approaches. Anticancer Res. 2017, 37, 2761-2775. [CrossRef]

40. Dawood, S.; Austin, L.; Cristofanilli, M. Cancer stem cells: Implications for cancer therapy. Oncology 2014, 28, $1101-1107$.

41. Subramaniam, D.; Kaushik, G.; Dandawate, P.; Anant, S. Targeting Cancer Stem Cells for Chemoprevention of Pancreatic Cancer. Curr. Med. Chem. 2018, 25, 2585-2594. [CrossRef] [PubMed]

42. Najumudeen, A.K.; Jaiswal, A.; Lectez, B.; Oetken-Lindholm, C.; Guzmán, C.; Siljamäki, E.; Posada, I.M.; Lacey, E.; Aittokallio, T.; Abankwa, D. Cancer stem cell drugs target K-ras signaling in a stemness context. Oncogene 2016, 35, 5248-5262. [CrossRef] [PubMed]

43. Zhou, H.M.; Dong, T.T.; Wang, L.L.; Feng, B.; Zhao, H.C.; Fan, X.K.; Zheng, M.H. Suppression of colorectal cancer metastasis by nigericin through inhibition of epithelial-mesenchymal transition. World J. Gastroenterol. 2012, 18, 2640-2648. [CrossRef]

44. Lamb, R.; Ozsvari, B.; Lisanti, C.L.; Tanowitz, H.B.; Howell, A.; Martinez-Outschoorn, U.E.; Sotgia, F.; Lisanti, M.P. Antibiotics that target mitochondria effectively eradicate cancer stem cells, across multiple tumor types: Treating cancer like an infectious disease. Oncotarget 2015, 6, 4569-4584. [CrossRef]

45. Balic, A.; Sørensen, M.D.; Trabulo, S.M.; Sainz, B., Jr.; Cioffi, M.; Vieira, C.R.; Miranda-Lorenzo, I.; Hidalgo, M.; Kleeff, J.; Erkan, M.; et al. Chloroquine targets pancreatic cancer stem cells via inhibition of CXCR4 and hedgehog signaling. Mol. Cancer Ther. 2014, 13, 1758-1771. [CrossRef]

46. Coyle, C.; Cafferty, F.H.; Rowley, S.; MacKenzie, M.; Berkman, L.; Gupta, S.; Pramesh, C.S.; Gilbert, D.; Kynaston, H.; Cameron, D.; et al. Add-Aspirin investigators. ADD-ASPIRIN: A phase III, double-blind, placebo controlled, randomised trial assessing the effects of aspirin on disease recurrence and survival after primary therapy in common non-metastatic solid tumours. Contemp. Clin. Trials 2016, 51, 56-64. [CrossRef]

47. Cong, J.; Wang, Y.; Zhang, X.; Zhang, N.; Liu, L.; Soukup, K.; Michelakos, T.; Hong, T.; DeLeo, A.; Cai, L.; et al. A novel chemoradiation targeting stem and nonstem pancreatic cancer cells by repurposing disulfiram. Cancer Lett. 2017, 409, 9-19. [CrossRef]

48. Garnier, A.; Vykoukal, J.; Hubertus, J.; Alt, E.; von Schweinitz, D.; Kappler, R.; Berger, M.; Ilmer, M. Targeting the neurokinin-1 receptor inhibits growth of human colon cancer cells. Int. J. Oncol. 2015, 47, 151-160. [CrossRef] [PubMed]

49. Fiorillo, M.; Lamb, R.; Tanowitz, H.B.; Mutti, L.; Krstic-Demonacos, M.; Cappello, A.R.; Martinez-Outschoorn, U.E.; Sotgia, F.; Lisanti, M.P. Repurposing atovaquone: Targeting mitochondrial complex III and OXPHOS to eradicate cancer stem cells. Oncotarget 2016, 7, 34084-34099. [CrossRef] [PubMed]

50. Zeng, J.Y.; Sharma, S.; Zhou, Y.Q.; Yao, H.P.; Hu, X.; Zhang, R.; Wang, M.H. Synergistic activities of MET/RON inhibitor BMS-777607 and mTOR inhibitor AZD8055 to polyploid cells derived from pancreatic cancer and cancer stem cells. Mol. Cancer Ther. 2014, 13, 37-48. [CrossRef] [PubMed]

51. Rangarajan, P.; Subramaniam, D.; Paul, S.; Kwatra, D.; Palaniyandi, K.; Islam, S.; Harihar, S.; Ramalingam, S.; Gutheil, W.; Putty, S. Crocetinic acid inhibits hedgehog signaling to inhibit pancreatic cancer stem cells. Oncotarget 2015, 6, 27661-27673. [CrossRef]

52. Miyazaki, Y.; Matsubara, S.; Ding, Q.; Tsukasa, K.; Yoshimitsu, M.; Kosai, K.; Takao, S. Efficient elimination of pancreatic cancer stem cells by hedgehog/GLI inhibitor GANT61 in combination with mTOR inhibition. Mol. Cancer 2016, 15, 49. [CrossRef] 
53. Blaj, C.; Bringmann, A.; Schmidt, E.M.; Urbischek, M.; Lamprecht, S.; Fröhlich, T.; Arnold, G.J.; Krebs, S.; Blum, H.; Hermeking, H. ADNP Is a Therapeutically Inducible Repressor of WNT Signaling in Colorectal Cancer. Clin. Cancer Res. 2017, 23, $2769-2780$. [CrossRef] [PubMed]

54. Reni, M.; Dugnani, E.; Cereda, S.; Belli, C.; Balzano, G.; Nicoletti, R.; Liberati, D.; Pasquale, V.; Scavini, M.; Maggiora, P.; et al. Irrelevance of Metformin Treatment in Patients with Metastatic Pancreatic Cancer: An Open-Label, Randomized Phase II Trial. Clin. Cancer Res. 2016, 22, 1076-1085. [CrossRef]

55. Ponnurangam, S.; Dandawate, P.R.; Dhar, A.; Tawfik, O.W.; Parab, R.R.; Mishra, P.D.; Ranadive, P.; Sharma, R.; Mahajan, G.; Umar, S. Quinomycin A targets Notch signaling pathway in pancreatic cancer stem cells. Oncotarget 2016, 7, 3217-3232. [CrossRef]

56. Matsubara, S.; Ding, Q.; Miyazaki, Y.; Kuwahata, T.; Tsukasa, K.; Takao, S. mTOR plays critical roles in pancreatic cancer stem cells through specific and stemness-related functions. Sci. Rep. 2013, 3, 3230. [CrossRef] [PubMed]

57. Abel, E.V.; Kim, E.J.; Wu, J.; Hynes, M.; Bednar, F.; Proctor, E.; Wang, L.; Dziubinski, M.L.; Simeone, D.M. The Notch pathway is important in maintaining the cancer stem cell population in pancreatic cancer. PLoS ONE 2014, 9, 91983. [CrossRef]

58. Ma, Y.; Yu, W.; Shrivastava, A.; Alemi, F.; Lankachandra, K.; Srivastava, R.K.; Shankar, S. Sanguinarine inhibits pancreatic cancer stem cell characteristics by inducing oxidative stress and suppressing sonic hedgehog-Gli-Nanog pathway. Carcinogenesis 2017, 38, 1047-1056. [CrossRef] [PubMed]

59. Renz, B.W.; D’Haese, J.G.; Werner, J.; Westphalen, C.B.; Ilmer, M. Repurposing Established Compounds to Target Pancreatic Cancer Stem Cells (CSCs). Med. Sci. 2017, 5, 14. [CrossRef]

60. Endo, Y.; Kitago, M.; Aiura, K.; Shinoda, M.; Yagi, H.; Abe, Y.; Oshima, G.; Hori, S.; Nakano, Y.; Itano, O.; et al. Efficacy and safety of preoperative 5-fluorouracil, cisplatin, and mitomycin $\mathrm{C}$ in combination with radiotherapy in patients with resectable and borderline resectable pancreatic cancer: A long-term follow-up study. World J. Surg. Oncol. 2019, 17, 1-8. [CrossRef]

61. Vreeland, T.J.; McAllister, F.; Javadi, S.; Prakash, L.R.; Fogelman, D.R.; Ho, L.; Varadhachary, G.; Aloia, T.A.; Vauthey, J.N.; Lee, J.E.; et al. Benefit of Gemcitabine/Nab-Paclitaxel Rescue of Patients With Borderline Resectable or Locally Advanced Pancreatic Adenocarcinoma After Early Failure of FOLFIRINOX. Pancreas 2019, 48, 837-843. [CrossRef]

62. Babiker, H.M.; Karass, M.; Recio-Boiles, A.; Chandana, S.R.; McBride, A.; Mahadevan, D. Everolimus for the treatment of advanced pancreatic ductal adenocarcinoma (PDAC). Exp. Opin. Investig. Drugs 2019, 28, 583-592. [CrossRef]

63. Patel, G.K.; Perry, J.B.; Abdul-Rahim, O.; Frankel, A.E.; Cameron, D.; Taylor, W.; Rocconi, R.P.; Abushahin, L.; Nelson, C.; Singh, A.P. Epidermal growth factor receptor-activating mutation (E746_T751> VP) in pancreatic ductal adenocarcinoma responds to erlotinib, followed by epidermal growth factor receptor resistance-mediating mutation (A647T): A case report and literature review. J. Cancer Res. Ther. 2020, 16, 950. [CrossRef]

64. Golan, T.; Varadhachary, G.R.; Sela, T.; Fogelman, D.R.; Halperin, N.; Shroff, R.T.; Halparin, S.; Xiao, L.; Aderka, D.; Maitra, A.; et al. Phase II study of olaparib for BRCAness phenotype in pancreatic cancer. J. Clin. Oncol. 2018, 36, 297. [CrossRef]

65. Mercadé, T.M.; Chen, L.T.; Li, C.P.; Siveke, J.T.; Cunningham, D.; Bodoky, G.; Blanc, J.F.; Lee, K.H.; Dean, A.; Belanger, B.; et al. Liposomal irinotecan+ 5-FU/LV in metastatic pancreatic cancer: Subgroup analyses of patient, tumor, and previous treatment characteristics in the pivotal NAPOLI-1 trial. Pancreas 2020, 49, 62. [CrossRef]

66. Gaustad, J.V.; Simonsen, T.G.; Wegner, C.S.; Rofstad, E.K. Vascularization, Oxygenation, and the Effect of Sunitinib Treatment in Pancreatic Ductal Adenocarcinoma Xenografts. Front. Oncol. 2019, 9, 845. [CrossRef] [PubMed]

67. Hong, Z.; Wang, Z.; Zhou, B.; Wang, J.; Tong, H.; Liao, Y.; Zheng, P.; Jamshed, M.B.; Zhang, Q.; Chen, H. Effects of evodiamine on PI3K/Akt and MAPK/ERK signaling pathways in pancreatic cancer cells. Int. J. Oncol. 2020, 56, 783-793. [CrossRef] [PubMed]

68. Grassilli, S.; Brugnoli, F.; Lattanzio, R.; Buglioni, S.; Bertagnolo, V. Vav1 Down-Modulates Akt2 Expression in Cells from Pancreatic Ductal Adenocarcinoma: Nuclear Vav1 as a Potential Regulator of Akt Related Malignancy in Pancreatic Cancer. Biomedicines 2020, 8, 379. [CrossRef] [PubMed]

69. Semba, T.; Sammons, R.; Wang, X.; Xie, X.; Dalby, K.N.; Ueno, N.T. JNK Signaling in Stem Cell Self-Renewal and Differentiation. Int. J. Mol. Sci. 2020, 21, 2613. [CrossRef]

70. Chen, Y.; Liu, P.; Shen, D.; Liu, H.; Xu, L.; Wang, J.; Shen, D.; Sun, H.; Wu, H. FAM172A inhibits EMT in pancreatic cancer via ERK-MAPK signaling. Biol. Open 2020, 9. [CrossRef]

71. Kaltschmidt, C.; Banz-Jansen, C.; Benhidjeb, T.; Beshay, M.; Förster, C.; Greiner, J.; Hamelmann, E.; Jorch, N.; Mertzlufft, F.; Pfitzenmaier, J.; et al. A role for NF-KB in organ specific cancer and cancer stem cells. Cancers 2019, 11, 655. [CrossRef] [PubMed]

72. Delle Cave, D.; Di Guida, M.; Costa, V.; Sevillano, M.; Ferrante, L.; Heeschen, C.; Corona, M.; Cucciardi, A.; Lonardo, E. TGF- $\beta 1$ secreted by pancreatic stellate cells promotes stemness and tumourigenicity in pancreatic cancer cells through L1CAM downregulation. Oncogene 2020, 1-15. [CrossRef]

73. Weekes, C.D.; Winn, R.A. The many faces of wnt and pancreatic ductal adenocarcinoma oncogenesis. Cancers 2011, 3, 3676-3686. [CrossRef] [PubMed]

74. Ram Makena, M.; Gatla, H.; Verlekar, D.; Sukhavasi, S.K.; Pandey, M.C.; Pramanik, K. Wnt/ $\beta$-Catenin Signaling: The Culprit in Pancreatic Carcinogenesis and Therapeutic Resistance. Int. J. Mol. Sci. 2019, 20, 4242. [CrossRef]

75. Beachy, P.A.; Hymowitz, S.G.; Lazarus, R.A.; Leahy, D.J.; Siebold, C. Interactions between Hedgehog proteins and their binding partners come into view. Genes Dev. 2010, 24, 2001-2012. [CrossRef] [PubMed]

76. Sari, I.N.; Phi, L.T.H.; Jun, N.; Wijaya, Y.T.; Lee, S.; Kwon, H.Y. Hedgehog signaling in cancer: A prospective therapeutic target for eradicating cancer stem cells. Cells 2018, 7, 208. [CrossRef] 
77. Takebe, N.; Miele, L.; Harris, P.J.; Jeong, W.; Bando, H.; Kahn, M.; Yang, S.X.; Ivy, S.P. Targeting Notch, Hedgehog, and Wnt pathways in cancer stem cells: Clinical update. Nat. Rev. Clin. Oncol. 2015, 12, 445-464. [CrossRef]

78. Gao, J.; Long, B.; Wang, Z. Role of Notch signaling pathway in pancreatic cancer. Am. J. Cancer Res. 2017, 7, 173-186. [PubMed]

79. Pelullo, M.; Zema, S.; Nardozza, F.; Checquolo, S.; Screpanti, I.; Bellavia, D. Wnt, Notch, and TGF- $\beta$ Pathways Impinge on Hedgehog Signaling Complexity: An Open Window on Cancer. Front. Genet. 2019, 10, 711. [CrossRef]

80. Bailey, J.M.; Alsina, J.; Rasheed, Z.A.; McAllister, F.M.; Fu, Y.Y.; Plentz, R.; Zhang, H.; Pasricha, P.J.; Bardeesy, N.; Matsui, W.; et al. DCLK1 marks a morphologically distinct subpopulation of cells with stem cell properties in preinvasive pancreatic cancer. Gastroenterology 2014, 146, 245-256. [CrossRef]

81. Thakur, G.; Lee, H.J.; Jeon, R.H.; Lee, S.L.; Rho, G.J. Small Molecule-Induced Pancreatic $\beta$-Like Cell Development: Mechanistic Approaches and Available Strategies. Int. J. Mol. Sci. 2020, 21, 2388. [CrossRef]

82. Castellanos, J.A.; Merchant, N.B.; Nagathihalli, N.S. Emerging targets in pancreatic cancer: Epithelial-mesenchymal transition and cancer stem cells. Onco. Targ. Ther. 2013, 6, 1261. [CrossRef]

83. Yang, Y.; Li, X.; Wang, T.; Guo, Q.; Xi, T.; Zheng, L. Emerging agents that target signaling pathways in cancer stem cells. J. Hematol. Oncol. 2020, 13, 1-18. [CrossRef] [PubMed]

84. Espinoza, I.; Miele, L. Notch inhibitors for cancer treatment. Pharmacol. Ther. 2013, 139, 95-110. [CrossRef]

85. Wang, Z.; Banerjee, S.; Li, Y.; Rahman, K.M.; Zhang, Y.; Sarkar, F.H. Down-regulation of notch-1 inhibits invasion by inactivation of nuclear factor-kappaB, vascular endothelial growth factor, and matrix metalloproteinase-9 in pancreatic cancer cells. Cancer Res. 2006, 66, 2778-2784. [CrossRef] [PubMed]

86. Blaumueller, C.M.; Qi, H.; Zagouras, P.; Artavanis-Tsakonas, S. Intracellular cleavage of Notch leads to a heterodimeric receptor on the plasma membrane. Cell 1997, 90, 281-291. [CrossRef]

87. Xie, M.; Zhang, L.; He, C.S.; Xu, F.; Liu, J.L.; Hu, Z.H.; Zhao, L.P.; Tian, Y. Activation of Notch-1 enhances epithelial-mesenchymal transition in gefitinib-acquired resistant lung cancer cells. J. Cell. Biochem. 2012, 113, 1501-1513. [CrossRef] [PubMed]

88. Gu, J.W.; Rizzo, P.; Pannuti, A.; Golde, T.; Osborne, B.; Miele, L. Notch signals in the endothelium and cancer "stem-like" cells: Opportunities for cancer therapy. Vasc. Cell 2012, 4, 7. [CrossRef]

89. Güngör, C.; Zander, H.; Effenberger, K.E.; Vashist, Y.K.; Kalinina, T.; Izbicki, J.R.; Yekebas, E.; Bockhorn, M. Notch signaling activated by replication stressinduced expression of midkine drives epithelial-mesenchymal transition and chemoresistance in pancreatic cancer. Cancer Res. 2011, 71, 5009-5019. [CrossRef] [PubMed]

90. Sethi, S.; Macoska, J.; Chen, W.; Sarkar, F.H. Molecular signature of epithelial- mesenchymal transition (EMT) in human prostate cancer bone metastasis. Am. J. Transl. Res. 2020, 3, 90-99.

91. Hu, H.; Zhou, L.; Awadallah, A.; Xin, W. Significance of Notch1-signaling pathway in human pancreatic development and carcinogenesis. Appl. Immunohistochem. Mol. Morphol. 2013, 21, 242-247. [CrossRef]

92. Vizio, B.; Mauri, F.A.; Prati, A.; Trivedi, P.; Giacobino, A.; Novarino, A.; Satolli, M.A.; Ciuffreda, L.; Camandona, M.; Gasparri, G.; et al. Comparative evaluation of cancer stem cell markers in normal pancreas and pancreatic ductal adenocarcinoma. Oncol. Rep. 2012, 27, 69-76. [CrossRef]

93. De La, O.J.; Emerson, L.L.; Goodman, J.L.; Froebe, S.C.; Illum, B.E.; Curtis, A.B.; Murtaugh, L.C. Notch and Kras reprogram pancreatic acinar cells to ductal intraepithelial neoplasia. Proc. Natl. Acad. Sci. USA 2008, 105, 18907-18912. [CrossRef]

94. Mazur, P.K.; Einwächter, H.; Lee, M.; Sipos, B.; Nakhai, H.; Rad, R.; Zimber-Strobl, U.; Strobl, L.J.; Radtke, F.; Klöppel, G.; et al. Notch2 is required for progression of pancreatic intraepithelial neoplasia and development of pancreatic ductal adenocarcinoma. Proc. Natl. Acad. Sci. USA 2010, 107, 13438-13443. [CrossRef] [PubMed]

95. Güngör, C.; Hofmann, B.T.; Wolters-Eisfeld, G.; Bockhorn, M. Pancreatic cancer. Br. J. Pharmacol. 2014, 171, 849-858. [CrossRef]

96. Buscail, L.; Bournet, B.; Cordelier, P. Role of oncogenic KRAS in the diagnosis, prognosis and treatment of pancreatic cancer. Nat. Rev. Gastroenterol. Hepatol. 2020, 17, 153-168. [CrossRef]

97. Reedijk, M.; Odorcic, S.; Chang, L.; Zhang, H.; Miller, N.; McCready, D.R.; Lockwood, G.; Egan, S.E. High-level coexpression of JAG1 and NOTCH1 is observed in human breast cancer and is associated with poor overall survival. Cancer Res. 2005, 65, 8530-8537. [CrossRef] [PubMed]

98. Bostad, M.; Berg, K.; Hogset, A.; Skarpen, E.; Stenmark, H.; Selbo, P.K. Photochemical internalization (PCI) of immunotoxins targeting CD133 is specific and highly potent at femtomolar levels in cells with cancer stem cell properties. J. Control. Release Off. J. Control. Release Soc. 2013, 168, 317-326. [CrossRef]

99. Işeri, Ö.D.; Kars, M.D.; Arpaci, F.; Atalay, C.; Pak, I.; Gündüz, U. Drug resistant MCF- 7 cells exhibit epithelial-mesenchymal transition gene expression pattern. Biomed. Pharmacother. 2011, 65, 40-45. [CrossRef] [PubMed]

100. Wang, Z.; Ahmad, A.; Li, Y.; Azmi, A.S.; Miele, L.; Sarkar, F.H. Targeting notch to eradicate pancreatic cancer stem cells for cancer therapy. Anticancer Res. 2011, 31, 1105-1113. [PubMed]

101. Song, H.Y.; Wang, Y.; Lan, H.; Zhang, Y.X. Expression of Notch receptors and their ligands in pancreatic ductal adenocarcinoma. Exp. Ther. Med. 2018, 16, 53-60. [CrossRef]

102. Li, Y.; Ma, J.; Qian, X.; Wu, Q.; Xia, J.; Miele, L.H.; Sarkar, F.; Wang, Z. Regulation of EMT by Notch Signaling Pathway in Tumor Progression. Curr. Cancer Drug Targ. 2013, 13, 957-962. [CrossRef] [PubMed]

103. Yabuuchi, S.; Pai, S.G.; Campbell, N.R.; De Wilde, R.F.; De Oliveira, E.; Korangath, P.; Streppel, M.M.; Rasheed, Z.A.; Hidalgo, M.; Maitra, A.; et al. Notch signaling pathway targeted therapy suppresses tumor progression and metastatic spread in pancreatic cancer. Cancer Lett. 2013, 335, 41-51. [CrossRef] [PubMed] 
104. Behnsawy, H.M.; Shigemura, K.; Meligy, F.Y.; Yamamichi, F.; Yamashita, M.; Haung, W.C.; Li, X.; Miyake, H.; Tanaka, K.; Kawabata, M.; et al. Possible role of sonic hedgehog and epithelial-mesenchymal transition in renal cell cancer progression. Kor. J. Urol. 2013, 54, 547-554. [CrossRef] [PubMed]

105. Merchant, A.A.; Matsui, W. Targeting Hedgehog—a cancer stem cell pathway. Clin. Cancer Res. 2010, 16, 3130-3140. [CrossRef]

106. Lei, J.; Ma, J.; Ma, Q.; Li, X.; Liu, H.; Xu, Q.; Duan, W.; Sun, Q.; Xu, J.; Wu, Z.; et al. Hedgehog signaling regulates hypoxia induced epithelial to mesenchymal transition and invasion in pancreatic cancer cells via a ligand-independent manner. Mol. Cancer 2013, 12, 1-11. [CrossRef] [PubMed]

107. Petrova, R.; Joyner, A.L. Roles for Hedgehog signaling in adult organ homeostasis and repair. Development 2014, 141 , 3445-3457. [CrossRef]

108. Wong, S.Y.; Reiter, J.F. The primary cilium at the crossroads of mammalian hedgehog signaling. Curr. Top. Dev. Biol. 2008, 85, 225-260. [CrossRef] [PubMed]

109. Odoux, C.; Fohrer, H.; Hoppo, T.; Guzik, L.; Stolz, D.B.; Lewis, D.W.; Gollin, S.M.; Gamblin, T.C.; Geller, D.A.; Lagasse, E. A stochastic model for cancer stem cell origin in metastatic colon cancer. Cancer Res. 2008, 68, 6932-6941. [CrossRef] [PubMed]

110. Li, Y.; Kong, D.; Ahmad, A.; Bao, B.; Sarkar, F.H. Pancreatic cancer stem cells: Emerging target for designing novel therapy. Cancer Lett. 2013, 338, 94-100. [CrossRef]

111. Hao, K.; Tian, X.D.; Qin, C.F.; Xie, X.H.; Yang, Y.M. Hedgehog signaling pathway regulates human pancreatic cancer cell proliferation and metastasis. Oncol. Rep. 2013, 29, 1124-1132. [CrossRef]

112. Barakat, M.T.; Humke, E.W.; Scott, M.P. Learning from Jekyll to control Hyde: Hedgehog signaling in development and cancer. Trends Mol. Med. 2010, 16, 337-348. [CrossRef]

113. Subramani, R.; Gonzalez, E.; Nandy, S.B.; Arumugam, A.; Camacho, F.; Medel, J.; Alabi, D.; Lakshmanaswamy, R. Gedunin inhibits pancreatic cancer by altering sonic hedgehog signaling pathway. Oncotarget 2017, 8, 10891. [CrossRef] [PubMed]

114. Ding, D.; Lim, K.S.; Eberhart, C.G. Arsenic trioxide inhibits Hedgehog, Notch and stem cell properties in glioblastoma neurospheres. Acta Neuropathol. Comm. 2014, 2, 31. [CrossRef]

115. Schreck, K.C.; Taylor, P.; Marchionni, L.; Gopalakrishnan, V.; Bar, E.E.; Gaiano, N.; Eberhart, C.G. The Notch target Hes1 directly modulates Gli1 expression and Hedgehog signaling: A potential mechanism of therapeutic resistance. Clin. Cancer Res. 2010, 16, 6060-6070. [CrossRef] [PubMed]

116. Wall, D.S.; Mears, A.J.; McNeill, B.; Mazerolle, C.; Thurig, S.; Wang, Y.; Kageyama, R.; Wallace, V.A. Progenitor cell proliferation in the retina is dependent on Notch-independent sonic hedgehog/Hes1 activity. J. Cell Biol. 2009, 184, 101-112. [CrossRef]

117. Ristorcelli, E.; Lombardo, D. Targeting Notch signaling in pancreatic cancer. Exp. Opin. Ther. Targ. 2010, 14, 541-552. [CrossRef]

118. Mohelnikova-Duchonova, B.; Kocik, M.; Duchonova, B.; Brynychova, V.; Oliverius, M.; Hlavsa, J.; Honsova, E.; Mazanec, J.; Kala, Z.; Ojima, I.; et al. Hedgehog pathway overexpression in pancreatic cancer is abrogated by new-generation taxoid SB-T-1216. Pharmacogenom. J. 2017, 17, 452-460. [CrossRef]

119. Collins, M.A.; Bednar, F.; Zhang, Y.; Brisset, J.C.; Galban, S.; Galban, C.J.; Rakshit, S.; Flannagan, K.S.; Adsay, N.V.; di Magliano, M.P. Oncogenic Kras is required for both the initiation and maintenance of pancreatic cancer in mice. J. Clin. Investig. 2012, 122, 639-653. [CrossRef] [PubMed]

120. Clevers, H. Wnt/beta-catenin signaling in development and disease. Cell 2006, 127, 469-480. [CrossRef]

121. Chien, A.J.; Conrad, W.H.; Moon, R.T. A Wnt survival guide: From flies to human disease. J. Investig. Dermatol. 2009, 129, 1614-1627. [CrossRef] [PubMed]

122. Cui, J.; Jiang, W.; Wang, S.; Wang, L.; Xie, K. Role of Wnt/ $\beta$-catenin signaling in drug resistance of pancreatic cancer. Curr. Pharm. Des. 2012, 18, 2464-2471. [CrossRef]

123. Liu, S.; Dontu, G.; Wicha, M.S. Mammary stem cells, self-renewal pathways, and carcinogenesis. Breast Cancer Res. 2005, 7, 86-95. [CrossRef]

124. Tiemann, K.; Heitling, U.; Kosmahl, M.; Kloppel, G. Solid pseudopapillary neoplasms of the pancreas show an interruption of the Wnt-signaling pathway and express gene products of 11q. Modern Pathol. 2007, 20, 955-960. [CrossRef]

125. Sano, M.; Driscoll, D.R.; DeJesus-Monge, W.E.; Quattrochi, B.; Appleman, V.A.; Ou, J.; Zhu, L.J.; Yoshida, N.; Yamazaki, S.; Takayama, T.; et al. Activation of WNT/ $\beta$-Catenin Signaling Enhances Pancreatic Cancer Development and the Malignant Potential Via Up-regulation of Cyr61. Neoplasia 2016, 18, 785-794. [CrossRef]

126. White, B.D.; Chien, A.J.; Dawson, D.W. Dysregulation of Wnt/beta-catenin signaling in gastrointestinal cancers. Gastroenterology 2012, 142, 219-232. [CrossRef]

127. Pires-daSilva, A.; Sommer, R.J. The evolution of signalling pathways in animal development. Nat. Rev. Genet. 2003, 4, 39-49. [CrossRef]

128. Zeng, Y.A.; Nusse, R. Wnt proteins are self-renewal factors for mammary stem cells and promote their long-term expansion in culture. Cell Stem Cell 2010, 6, 568-577. [CrossRef]

129. Li, X.Y.; Zhai, W.J.; Teng, C.B. Notch Signaling in Pancreatic Development. Int. J. Mol. Sci. 2016, 17, 48. [CrossRef] [PubMed]

130. Thiery, J.P.; Acloque, H.; Huang, R.Y.; Nieto, M.A. Epithelial-mesenchymal transitions in development and disease. Cell 2009, 139, 871-890. [CrossRef] [PubMed]

131. Thiery, J.P. Epithelial-mesenchymal transitions in cancer onset and progression. Bull. Acad. Nat. Med. 2009, 193, 1969-1978. [CrossRef] [PubMed] 
132. Espinoza, I.; Miele, L. Deadly crosstalk: Notch signaling at the intersection of EMT and cancer stem cells. Cancer Lett. 2013, 341, 41-45. [CrossRef]

133. Potenta, S.; Zeisberg, E.; Kalluri, R. The role of endothelial-to-mesenchymal transition in cancer progression. Br. J. Cancer 2008, 99, 1375-1379. [CrossRef]

134. Wang, Y.; Zhou, B.P. Epithelial-mesenchymal transition in breast cancer progression and metastasis. Chin. J. Cancer 2011, 30, 603-611. [CrossRef]

135. Dudás, J.; Ladányi, A.; Ingruber, J.; Steinbichler, T.B.; Riechelmann, H. Epithelial to Mesenchymal Transition: A Mechanism that Fuels Cancer Radio/Chemoresistance. Cells 2020, 9, 428. [CrossRef]

136. Ciernikova, S.; Earl, J.; García Bermejo, M.L.; Stevurkova, V.; Carrato, A.; Smolkova, B. Epigenetic Landscape in Pancreatic Ductal Adenocarcinoma: On the Way to Overcoming Drug Resistance? Int. J. Mol. Sci. 2020, 21, 4091. [CrossRef]

137. Thompson, M.J.; Rubbi, L.; Dawson, D.W.; Donahue, T.R.; Pellegrini, M. Pancreatic cancer patient survival correlates with DNA methylation of pancreas development genes. PLoS ONE 2015, 10, e0128814. [CrossRef]

138. Liu, Z.; Gao, Y.; Li, X. Cancer epigenetics and the potential of epigenetic drugs for treating solid tumors. Exp. Rev. Anticancer Ther. 2019, 19, 139-149. [CrossRef] [PubMed]

139. Burk, U.; Schubert, J.; Wellner, U.; Schmalhofer, O.; Vincan, E.; Spaderna, S.; Brabletz, T. A reciprocal repression between ZEB1 and members of the miR-200 family promotes EMT and invasion in cancer cells. EMBO Rep. 2008, 9, 582-589. [CrossRef] [PubMed]

140. Schmalhofer, O.; Brabletz, S.; Brabletz, T. E-cadherin, $\beta$-catenin, and ZEB1 in malignant progression of cancer. Cancer Metastasis Rev. 2009, 28, 151-166. [CrossRef] [PubMed]

141. Aigner, K.; Dampier, B.; Descovich, L.; Mikula, M.; Sultan, A.; Schreiber, M.; Mikulits, W.; Brabletz, T.; Strand, D.; Obrist, P.; et al. The transcription factor ZEB1 $(\delta \mathrm{EF} 1)$ promotes tumour cell dedifferentiation by repressing master regulators of epithelial polarity. Oncogene 2007, 26, 6979-6988. [CrossRef] [PubMed]

142. Zhang, Y.; Xu, L.; Li, A.; Han, X. The roles of ZEB1 in tumorigenic progression and epigenetic modifications. Biomed. Pharmacother. 2019, 110, 400-408. [CrossRef] [PubMed]

143. Wellner, U.; Schubert, J.; Burk, U.C.; Schmalhofer, O.; Zhu, F.; Sonntag, A.; Waldvogel, B.; Vannier, C.; Darling, D.; Zur Hausen, A.; et al. The EMT-activator ZEB1 promotes tumorigenicity by repressing stemness-inhibiting microRNAs. Nat. Cell Biol. 2009, 11, 1487-1495. [CrossRef] [PubMed]

144. Chen, B.; Chen, B.; Zhu, Z.; Ye, W.; Zeng, J.; Liu, G.; Wang, S.; Gao, J.; Xu, G.; Huang, Z. Prognostic value of ZEB-1 in solid tumors: A meta-analysis. BMC Cancer 2019, 19, 635. [CrossRef] [PubMed]

145. Sriram, K.; Salmerón, C.; Wiley, S.Z.; Insel, P.A. GPCRs in pancreatic adenocarcinoma: Contributors to tumour biology and novel therapeutic targets. Br. J. Pharmacol. 2020, 177, 2434-2455. [CrossRef]

146. Hauser, A.S.; Chavali, S.; Masuho, I.; Jahn, L.J.; Martemyanov, K.A.; Gloriam, D.E.; Babu, M.M. Pharmacogenomics of GPCR Drug Targets. Cell 2018, 172, 41-54. [CrossRef]

147. Lappano, R.; Maggiolini, M. G protein-coupled receptors: Novel targets for drug discovery in cancer. Nat. Rev. Drug Discov. 2011, 10, 47-60. [CrossRef]

148. Hothersall, J.D.; Brown, A.J.; Dale, I.; Rawlins, P. Can residence time offer a useful strategy to target agonist drugs for sustained GPCR responses? Drug Discov. Today 2016, 21, 90-96. [CrossRef] [PubMed]

149. Natale, C.A.; Li, J.; Pitarresi, J.R.; Norgard, R.J.; Dentchev, T.; Capell, B.C.; Seykora, J.T.; Stanger, B.Z.; Ridky, T.W. Pharmacologic Activation of the G Protein-Coupled Estrogen Receptor Inhibits Pancreatic Ductal Adenocarcinoma. Cell. Mol. Gastroenterol. Hepatol. 2020, 10, 868-880. [CrossRef] [PubMed]

150. Chimento, A.; Sirianni, R.; Casaburi, I.; Zolea, F.; Rizza, P.; Avena, P.; Malivindi, R.; De Luca, A.; Campana, C.; Martire, E.; et al. GPER agonist G-1 decreases adrenocortical carcinoma (ACC) cell growth in vitro and in vivo. Oncotarget 2015, 6, 19190-19203. [CrossRef]

151. Koppula, P.; Zhuang, L.; Gan, B. Cystine transporter SLC7A11/xCT in cancer: Ferroptosis, nutrient dependency, and cancer therapy. Protein Cell 2020, 1-22. [CrossRef]

152. Daher, B.; Parks, S.K.; Durivault, J.; Cormerais, Y.; Baidarjad, H.; Tambutte, E.; Pouysségur, J.; Vučetić, M. Genetic ablation of the cystine transporter $\mathrm{xCT}$ in PDAC cells inhibits mTORC1, growth, survival, and tumor formation via nutrient and oxidative stresses. Cancer Res. 2019, 79, 3877-3890. [CrossRef]

153. Badgley, M.A.; Kremer, D.M.; Maurer, H.C.; DelGiorno, K.E.; Lee, H.J.; Purohit, V.; Sagalovskiy, I.R.; Ma, A.; Kapilian, J.; Firl, C.E.; et al. Cysteine depletion induces pancreatic tumor ferroptosis in mice. Science 2020, 368, 85-89. [CrossRef]

154. Bannai, S.; Tsukeda, H.; Okumura, H. Effect of antioxidants on cultured human diploid fibroblasts exposed to cystine-free medium. Biochem. Biophys. Res. Commun. 1977, 74, 1582-1588. [CrossRef]

155. Vander Heiden, M.G.; Cantley, L.C.; Thompson, C.B. Understanding the Warburg effect: The metabolic requirements of cell proliferation. Science 2009, 324, 1029-1033. [CrossRef] [PubMed]

156. Mazurek, S. Pyruvate kinase type M2: A key regulator of the metabolic budget system in tumor cells. Int. J. Biochem. Cell Biol. 2011, 43, 969-980. [CrossRef] [PubMed]

157. Marie, J.; Levin, M.J.; Simon, M.P.; Kahn, A. Genetic and epigenetic control of the pyruvate kinase isozymes in mammals. Isozymes 1983, 7, 221-240. [PubMed]

158. Dong, G.; Mao, Q.; Xia, W.; Xu, Y.; Wang, J.; Xu, L.; Jiang, F. PKM2 and cancer: The function of PKM2 beyond glycolysis. Oncology Lett. 2016, 11, 1980-1986. [CrossRef] [PubMed] 
159. Li, C.; Zhao, Z.; Zhou, Z.; Liu, R. PKM2 promotes cell survival and invasion under metabolic stress by enhancing Warburg effect in pancreatic ductal adenocarcinoma. Digest. Dis. Sci. 2016, 61,767-773. [CrossRef]

160. James, A.D.; Richardson, D.A.; Oh, I.W.; Sritangos, P.; Attard, T.; Barrett, L.; Bruce, J.I. Cutting off the fuel supply to calcium pumps in pancreatic cancer cells: Role of pyruvate kinase-M2 (PKM2). Br. J. Cancer 2020, 122, 266-278. [CrossRef]

161. James, A.D.; Patel, W.; Butt, Z.; Adiamah, M.; Dakhel, R.; Latif, A.; Uggenti, C.; Swanton, E.; Imamura, H.; Siriwardena, A.K.; et al The plasma membrane calcium pump in pancreatic cancer cells exhibiting the Warburg effect relies on glycolytic ATP. J. Biol. Chem. 2015, 290, 24760-24771. [CrossRef]

162. Yokoyama, M.; Tanuma, N.; Shibuya, R.; Shiroki, T.; Abue, M.; Yamamoto, K.; Miura, K.; Yamaguchi, K.; Sato, I.; Tamai, K.; et al. Pyruvate kinase type M2 contributes to the development of pancreatic ductal adenocarcinoma by regulating the production of metabolites and reactive oxygen species. Int. J. Oncol. 2018, 52, 881-891. [CrossRef] [PubMed]

163. Cheng, T.Y.; Yang, Y.C.; Wang, H.P.; Tien, Y.W.; Shun, C.T.; Huang, H.Y.; Hsiao, M.; Hua, K.T. Pyruvate kinase M2 promotes pancreatic ductal adenocarcinoma invasion and metastasis through phosphorylation and stabilization of PAK2 protein. Oncogene 2018, 37, 1730-1742. [CrossRef]

164. Chen, J.; Xie, J.; Jiang, Z.; Wang, B.; Wang, Y.; Hu, X. Shikonin and its analogs inhibit cancer cell glycolysis by targeting tumor pyruvate kinase-M2. Oncogene 2011, 30, 4297-4306. [CrossRef]

165. Schenk, M.; Aykut, B.; Teske, C.; Giese, N.A.; Weitz, J.; Welsch, T. Salinomycin inhibits growth of pancreatic cancer and cancer cell migration by disruption of actin stress fiber integrity. Cancer Lett. 2015, 358, 161-169. [CrossRef]

166. Wang, W.; Zhao, Y.; Yao, S.; Cui, X.; Pan, W.; Huang, W.; Gao, J.; Dong, T.; Zhang, S. Nigericin inhibits epithelial ovarian cancer metastasis by suppressing the cell cycle and epithelial-mesenchymal transition. Biochem. Moscow 2017, 82, 933-941. [CrossRef] [PubMed]

167. Mohammed, A.; Janakiram, N.B.; Brewer, M.; Ritchie, R.L.; Marya, A.; Lightfoot, S.; Steele, V.E.; Rao, C.V. Antidiabetic Drug Metformin Prevents Progression of Pancreatic Cancer by Targeting in Part Cancer Stem Cells and mTOR Signaling. Transl. Oncol. 2013, 6, 649-659. [CrossRef] [PubMed]

168. Nechushtan, H.; Hamamreh, Y.; Nidal, S.; Gotfried, M.; Baron, A.; Shalev, Y.I.; Nisman, B.; Peretz, T.; Peylan-Ramu, N. A phase IIb trial assessing the addition of disulfiram to chemotherapy for the treatment of metastatic non-small cell lung cancer. Oncologist 2015, 20, 366-367. [CrossRef]

169. Neesse, A.; Michl, P.; Frese, K.K.; Feig, C.; Cook, N.; Jacobetz, M.A.; Lolkema, M.P.; Buchholz, M.; Olive, K.P.; Gress, T.M.; et al. Stromal biology and therapy in pancreatic cancer. Gut 2011, 60, 861-868. [CrossRef] [PubMed]

170. Lonardo, E.; Frias-Aldeguer, J.; Hermann, P.C.; Heeschen, C. Pancreatic stellate cells form a niche for cancer stem cells and promote their self-renewal and invasiveness. Cell Cycle 2012, 11, 1282-1290. [CrossRef] [PubMed]

171. Wörmann, S.M.; Diakopoulos, K.N.; Lesina, M.; Algül, H. The immune network in pancreatic cancer development and progression. Oncogene 2014, 33, 2956-2967. [CrossRef] [PubMed]

172. Shi, C.; Washington, M.K.; Chaturvedi, R.; Drosos, Y.; Revetta, F.L.; Weaver, C.J.; Buzhardt, E.; Yull, F.E.; Blackwell, T.S.; SosaPineda, B.; et al. Fibrogenesis in pancreatic cancer is a dynamic process regulated by macrophage-stellate cell interaction. Lab. Investig. 2014, 94, 409-421. [CrossRef] [PubMed]

173. Ene-Obong, A.; Clear, A.J.; Watt, J.; Wang, J.; Fatah, R.; Riches, J.C.; Marshall, J.F.; Chin-Aleong, J.; Chelala, C.; Gribben, J.G.; et al. Activated pancreatic stellate cells sequester CD8+ T cells to reduce their infiltration of the juxtatumoral compartment of pancreatic ductal adenocarcinoma. Gastroenterology 2013, 145, 1121-1132. [CrossRef]

174. Tang, D.; Gao, J.; Wang, S.; Yuan, Z.; Ye, N.; Chong, Y.; Xu, C.; Jiang, X.; Li, B.; Yin, W.; et al. Apoptosis and anergy of T cell induced by pancreatic stellate cells-derived galectin-1 in pancreatic cancer. Tumor Biol. 2015, 36, 5617-5626. [CrossRef] [PubMed]

175. Minici, C.; Rigamonti, E.; Lanzillotta, M.; Monno, A.; Rovati, L.; Maehara, T.; Kaneko, N.; Deshpande, V.; Protti, M.P.; De Monte, L.; et al. B lymphocytes contribute to stromal reaction in pancreatic ductal adenocarcinoma. Oncoimmunology 2020, 9 , 1794359. [CrossRef]

176. Yuen, G.J.; Demissie, E.; Pillai, S. B lymphocytes and cancer: A love-hate relationship. Trends Cancer 2016, 2, 747-757. [CrossRef]

177. Le, D.T.; Jaffee, E.M. Next-generation cancer vaccine approaches: Integrating lessons learned from current successes with promising biotechnologic advances. J. Natl. Compr. Cancer Network 2013, 11, 766-772. [CrossRef] [PubMed]

178. Pardoll, D.M. The blockade of immune checkpoints in cancer immunotherapy. Nat. Rev. Cancer 2012, 12, 252-264. [CrossRef] [PubMed]

179. Gibney, G.T.; Weiner, L.M.; Atkins, M.B. Predictive biomarkers for checkpoint inhibitor-based immunotherapy. Lancet Oncol. 2016, 17, 542-551. [CrossRef]

180. Zhang, J.; Wolfgang, C.L.; Zheng, L. Precision Immuno-Oncology: Prospects of Individualized Immunotherapy for Pancreatic Cancer. Cancers 2018, 10, 39. [CrossRef] [PubMed]

181. Iwai, Y.; Ishida, M.; Tanaka, Y.; Okazaki, T.; Honjo, T.; Minato, N. Involvement of PD-L1 on tumor cells in the escape from host immune system and tumor immunotherapy by PD-L1 blockade. Proc. Natl. Acad. Sci. USA 2002, 99, 12293-12297. [CrossRef] [PubMed]

182. AstraZeneca. Study of Tremelimumab in Patients with Advanced Solid Tumors. 2015. Available online: https://clinicaltrials. gov/show / NCT02527434 (accessed on 20 December 2020).

183. Blank, C.U.; Enk, A. Therapeutic use of anti-CTLA-4 antibodies. Int. Immunol. 2015, 27, 3-10. [CrossRef] 
184. O'Reilly, E.M.; Oh, D.Y.; Dhani, N.; Renouf, D.J.; Lee, M.A.; Sun, W.; Fisher, G.; Hezel, A.; Chang, S.C.; Vlahovic, G.; et al. Durvalumab With or Without Tremelimumab for Patients With Metastatic Pancreatic Ductal Adenocarcinoma: A Phase 2 Randomized Clinical Trial. JAMA Oncol. 2019, 5, 1431-1438. [CrossRef]

185. Kamath, S.D.; Kalyan, A.; Kircher, S.; Nimeiri, H.; Fought, A.J.; Benson, A.; Mulcahy, M. Ipilimumab and Gemcitabine for Advanced Pancreatic Cancer: A Phase Ib Study. Oncologist 2020, 25, 808-815. [CrossRef]

186. Weiss, G.J.; Blaydorn, L.; Beck, J.; Bornemann-Kolatzki, K.; Urnovitz, H.; Schutz, E.; Khemka, V. Correction to: Phase Ib/II study of gemcitabine, nab-paclitaxel, and pembrolizumab in metastatic pancreatic adenocarcinoma. Investig. New Drugs $2019,37,797$. [CrossRef]

187. Schizas, D.; Charalampakis, N.; Kole, C.; Economopoulou, P.; Koustas, E.; Gkotsis, E.; Ziogas, D.; Psyrri, A.; Karamouzis, M.V. Immunotherapy for pancreatic cancer: A 2020 update. Cancer Treat. Rev. 2020, 86, 102016. [CrossRef] [PubMed]

188. Thomas, A.M.; Santarsiero, L.M.; Lutz, E.R.; Armstrong, T.D.; Chen, Y.C.; Huang, L.Q.; Laheru, D.A.; Goggins, M.; Hruban, R.H.; Jaffee, E.M. Mesothelin-specific CD8(+) T cell responses provide evidence of in vivo cross-priming by antigen-presenting cells in vaccinated pancreatic cancer patients. J. Exp. Med. 2004, 200, 297-306. [CrossRef] [PubMed]

189. Le, D.T.; Picozzi, V.J.; Ko, A.H.; Wainberg, Z.A.; Kindler, H.; Wang-Gillam, A.; Oberstein, P.; Morse, M.A.; Zeh, H.J.; Weekes, C.; et al. Results from a Phase IIb, Randomized, Multicenter Study of GVAX Pancreas and CRS-207 Compared with Chemotherapy in Adults with Previously Treated Metastatic Pancreatic Adenocarcinoma (ECLIPSE Study). Clin. Cancer Res. 2019, 25, 5493-5502. [CrossRef]

190. Le, D.T.; Lutz, E.; Uram, J.N.; Sugar, E.A.; Onners, B.; Solt, S.; Zheng, L.; Diaz, L.A.; Donehower, R.C.; Jaffee, E.M.; et al. Evaluation of ipilimumab in combination with allogeneic pancreatic tumor cells transfected with a GM-CSF gene in previously treated pancreatic cancer. J. Immunother. 2013, 36, 382-389. [CrossRef]

191. Thind, K.; Padrnos, L.J.; Ramanathan, R.K.; Borad, M.J. Immunotherapy in pancreatic cancer treatment: A new frontier. Ther. Adv. Gastroenterol. 2017, 10, 168-194. [CrossRef] [PubMed]

192. Beatty, G.L.; Torigian, D.A.; Chiorean, E.G.; Saboury, B.; Brothers, A.; Alavi, A.; Troxel, A.B.; Sun, W.; Teitelbaum, U.R.; Vonderheide, R.H.; et al. A phase I study of an agonist CD40 monoclonal antibody (CP- 870,893) in combination with gemcitabine in patients with advanced pancreatic ductal adenocarcinoma. Clin. Cancer Res. 2013, 19, 6286-6295. [CrossRef]

193. Nywening, T.M.; Wang-Gillam, A.; Sanford, D.E.; Belt, B.A.; Panni, R.Z.; Cusworth, B.M.; Toriola, A.T.; Nieman, R.K.; Worley, L.A.; Yano, M.; et al. Targeting tumour-associated macrophages with CCR2 inhibition in combination with FOLFIRINOX in patients with borderline resectable and locally advanced pancreatic cancer: A single-centre, open-label, dose-finding, nonrandomised, phase $1 \mathrm{~b}$ trial. Lancet Oncol. 2016, 17, 651-662. [CrossRef]

194. Chiossone, L.; Dumas, P.Y.; Vienne, M.; Vivier, E. Natural killer cells and other innate lymphoid cells in cancer. Nat. Rev. Immunol. 2018, 18, 671-688. [CrossRef] [PubMed]

195. Van Audenaerde, J.; Roeyen, G.; Darcy, P.K.; Kershaw, M.H.; Peeters, M.; Smits, E. Natural killer cells and their therapeutic role in pancreatic cancer: A systematic review. Pharmacol. Ther. 2018, 189, 31-44. [CrossRef]

196. Lee, J.; Kang, T.H.; Yoo, W.; Choi, H.; Jo, S.; Kong, K.; Lee, S.R.; Kim, S.U.; Kim, J.S.; Cho, D.; et al. An antibody designed to improve adoptive NK-cell therapy inhibits pancreatic cancer progression in a murine model. Cancer Immunol. Res. 2019, 7, 219-229. [CrossRef]

197. Goedegebuure, P.; Mitchem, J.B.; Porembka, M.R.; Tan, M.C.; Belt, B.A.; WangGillam, A.E.; Gillanders, W.G.; Hawkins, W.C.; Linehan, D. Myeloid-derived suppressor cells: General characteristics and relevance to clinical management of pancreatic cancer. Curr. Cancer Drug Targ. 2011, 11, 734-751. [CrossRef] [PubMed]

198. D'Alterio, C.; Scala, S.; Sozzi, G.; Roz, L.; Bertolini, G. Paradoxical effects of chemotherapy on tumor relapse and metastasis promotion. Semin. Cancer Biol. 2020, 60, 351-361. [CrossRef] [PubMed]

199. Han, J.; Won, M.; Kim, J.H.; Jung, E.; Min, K.; Jangili, P.; Kim, J.S. Cancer stem cell-targeted bio-imaging and chemotherapeutic perspective. Chem. Soc. Rev. 2020, 49, 7856-7878. [CrossRef] [PubMed]

200. Aponte, P.M.; Caicedo, A. Stemness in cancer: Stem cells, cancer stem cells, and their microenvironment. Stem Cells Int. 2017. [CrossRef]

201. Razidlo, G.L.; Magnine, C.; Sletten, A.C.; Hurley, R.M.; Almada, L.L.; Fernandez-Zapico, M.E.; Ji, B.; McNiven, M.A. Targeting pancreatic cancer metastasis by inhibition of Vav1, a driver of tumor cell invasion. Cancer Res. 2015, 75, 2907-2915. [CrossRef] 